\title{
THE INFORMATION SEMICOMMONS
}

\author{
By Robert A. Heverly ${ }^{\dagger}$
}

\begin{abstract}
We think of information as property; law and economic structures, we argue, make it so. But this should not be the end of our inquiry. If we believe information is property, we must ask: What kind of property is information? While at times common use of information, even privately owned information, is accepted under the guise of fair use, private ownership of information forms the bedrock of our understanding of the information property regime. Common uses, when allowed, are perceived as infringements on the private owner's property rights.

This Article argues that this perception is mistaken: we may think of information as owned, but ownership need not be based in a purely private ownership scheme. Information ownership is instead a semicommons, a property model that explicitly recognizes the dynamic relationship and interdependence of private and common property uses.

Using the example of peer-to-peer file sharing, this Article applies semicommons theory to information, and shows that this application has broad implications for decisionmaking in the digital age. Through the lens of the semicommons, we realize that common uses are part of the very structure of an accurately described information ownership regime. As such, common uses increase the overall societal benefits that flow from information creation and should not only be tolerated, but encouraged.

Information is not a private property regime: it is a semicommons.
\end{abstract}

\section{TABLE OF CONTENTS}

I. INTRODUCTION

II. TeChNOlogical TENSION: PEER-TO-PEER FILE SHARING

III. The CurRent Debate: The Tension Between Private AND Common Uses . 1139

(C) 2003 Robert A. Heverly

$\dagger$ Lecturer in Law and Director of the LL.M. Programme in Intellectual Property Law at the Norwich Law School, University of East Anglia, England. The majority of work on this Article was completed while the author was a Resident Fellow at the Information Society Project at Yale Law School. The following people have provided invaluable assistance and comments on this Article: Henry Smith, Jack Balkin, Caio Mario da Silva Pereia Neto, Nimrod Kozlovski, Shlomit Wagman, James Grimmelman, Markus Gehring, participants in the Graduate Workshop at Yale Law School, and participants at a Faculty Development Workshop at Albany Law School. Robert received his LL.M. from Yale Law School and his J.D. from Albany Law School of Union University. 


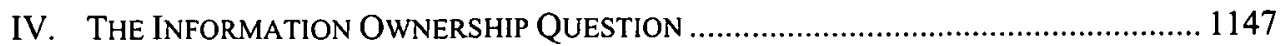

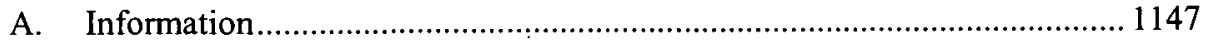

B. Owning Information: A Framework for Inquiry ....................................1151

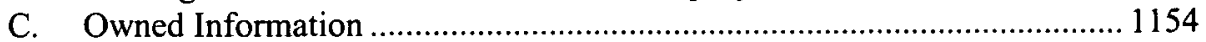

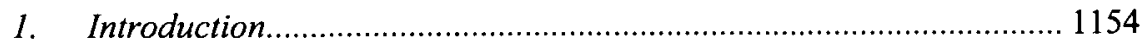

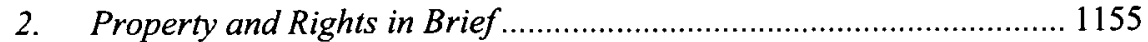

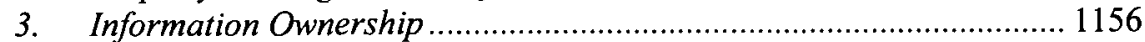

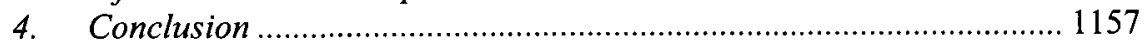

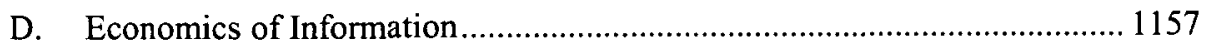

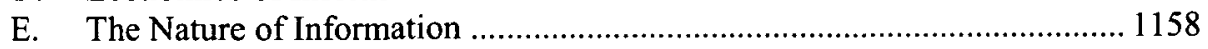

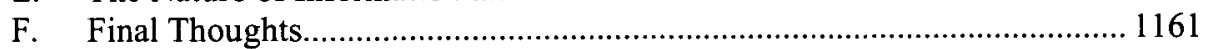

V. INFORMATION OWNERSHIP AS A SEMICOMMONS........................................... 1161

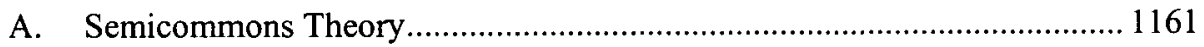

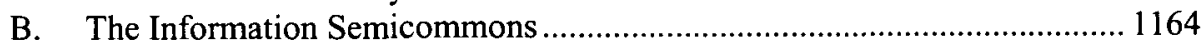

1. Private and Common: Information Use Dynamics ............................ 1165

2. Information "Creation" and Information Dynamics ......................... 1167

3. Strategic Behavior in the Information Semicommons ....................... 1172

a) Identifying Strategic Behavior in the Information Semicommons . 1172

b) Avoiding Strategic Behavior .................................................... 1178

c) The Digital Revolution and Strategic Behavior........................... 1181

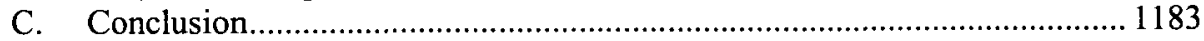

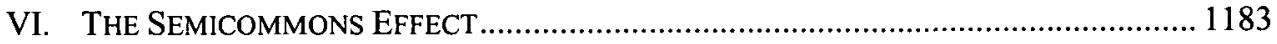

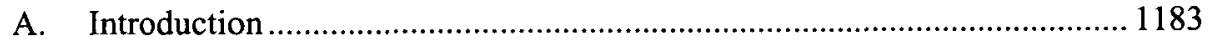

B. The Normative Effect of the Semicommons Approach: Acknowledging

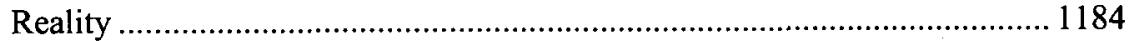

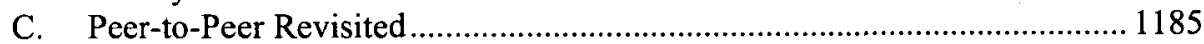

D. Using Content and Distribution Level Interactions in Decisionmaking ..... 1187

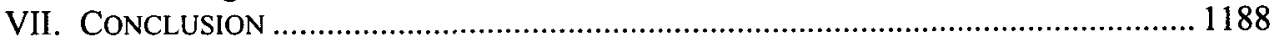

\section{INTRODUCTION}

When the curtains open, information is at center stage. Economically, in terms of speech, creativity, entertainment, and public discourse, information is the focus of much of life today. Our responses to the increased importance of information have predictably been shaped by our experience.

Specifically, we believe that information creators and distributors, the holders of copyrights, patents, trademarks and trade secrets, own the information they have created or seek to protect. Statutory provisions and judicial interpretations support this belief. In the modern case, information ownership is viewed as something akin to the ownership of land-as an asset to be used efficiently. Within the legal and economic structures that define the ownership of information, we treat information as property. ${ }^{1}$

1. This Article does not advocate the position that information is in fact property, but rather that through our perception of it as such, we have failed to go further and ask the questions necessary to tell us what kind of property information should be. Those 
Our conception of private ownership of information may be subject to some caveats, ${ }^{2}$ but the general and overarching theme of information ownership is the private use and control of information.

However, when discussing the ownership of information, we generally fail to ask what kind of ownership applies to information. This question is particularly relevant to peer-to-peer file trading applications: networked systems that allow users to exchange digital media files, the content of which is held as property by someone else. ${ }^{3}$ Control over distributionalso known as the right to exclude others from using or distributing-is one of the key rights that private users have over their property. ${ }^{4}$ Peer-topeer file sharing appears to shred this right, providing an apparent technological end-run around the private rights of copyright owners.

It should thus not be surprising that lawsuits followed the widespread deployment of peer-to-peer technology. ${ }^{5}$ The lawsuits were based on, and decided upon, our perception that information is property. On the whole, the legal disputes show how firmly ingrained the private notion of information ownership is in our legal, cultural, and societal psyche. The plaintiffs argued that peer-to-peer users were stealing their property, whereas users argued that they were making legally acceptable use of the property. The courts decided the cases based on the private use rights of the information owners.

This fact must not be understated: the legal decisions issued by courts involving peer-to-peer applications have been based on a conception of information as private property. ${ }^{6}$ As a result, courts have shut down poten-

critical of the notion that information is property will quite expectedly reject the notion that information is a particular kind of property. Thus, the basic argument-that information is property-is described, but not stridently defended, so as to reach the important question of the nature of information as property when we perceive it as such.

2. Such caveats might include, for example, fair use. See 17 U.S.C. $\S 107$ (2000).

3. Peer-to-peer file trading systems are used here as one particularly trenchant example of the problems inherent in our current perception of information as property, but they are by no means the only one.

4. See, e.g., Thomas W. Merrill, Property and the Right to Exclude, 77 NEB. L. REV. 730 (1998) (arguing that the right to exclude others is the most important of all property rights).

5. See, e.g., Metro-Goldwyn-Mayer Studios, Inc. v. Grokster, Ltd., 259 F. Supp. 2d 1029 (C.D. Cal. 2003); In re Aimster Copyright Litig., 252 F. Supp. 2 d 634 (N.D. Ill. 2002); A\&M Records, Inc. v. Napster, Inc., 114 F. Supp. 2d 896, 913 (N.D. Cal. 2000) [hercinafter Napster I], aff'd in part, rev'd in part, 239 F.3d 1004 (9th Cir. 2001) [hereinafter Napster II], remanded to No. C 99-05183, 2001 U.S. Dist. LEXIS 2186 (C.D. Cal. Mar. 5 2001) [hereinafter Napster III], aff'd, 284 F.3d 1091 (9th Cir. 2002) [hereinafter Napster IV]; see also infra notes 19-23 and accompanying text.

6. See cases cited supra note 5 . 
tially liberating, freeing, equalizing technological applications that take full advantage of the decentralized nature of networks such as the Internet.

But this Article does not argue that such technologies should be spared solely because of alternative or empowering uses that are not currently at the core of their operations. Rather, it argues that the trading of copyright protected files via peer-to-peer networks is itself a valid reflection of the nature of the information ownership regime. Indeed, it argues that such use of peer-to-peer systems should be accepted and endorsed by the legal system under certain circumstances-some of which are reflected in current doctrine.

The implications of such an argument are broad and far-reaching. They would require the consideration of new policy implications when deciding whether to extend private uses and protections in information, affect judicial decisionmaking relating to use of existing information, and-as in the case we will study here-have implications for common use of information that is subject to copyright protection. Trademark, copyright, trade secret, and patent law would all be affected, as would all the arenas of economic, political, and legal decisionmaking that touch information.

To sustain such claims, to support the call for such a shift in paradigm, this Article makes a number of descriptive claims relating to information and information ownership. The positive claims begin with the idea that judicial decisions ordering peer-to-peer software to preclude the sharing of protected files, or holding software creators liable for infringement that occurs using their products and supporting networks, are based on the understanding of intellectual property as private property, with common uses viewed as infringements on the rights of the property owners. Even fair use is viewed within the structure of property as a defense to infringement; use is not a right per se of common users, but rather can be advanced as a defense once infringement has been proven or acknowledged. Fair use is measured against the private exploitation rights of the information owner.

This view of information as private property, of fair use as a perhaps barely tolerable infringement on private users' rights, though widely accepted, is incorrect. Information ownership can better be described as a semicommons, ${ }^{7}$ a form of ownership that acknowledges the dynamic rela-

7. See Henry E. Smith, Semicommon Property Rights and Scattering in the Open Fields, 29 J. LEGAL STUD. 131 (2000). Semicommons theory has much to offer in this regard, as a way of explaining how private and common uses of information might coexist, in contrast to what in the past has been portrayed as a primarily antagonistic relationship. 
tionship between private and common uses. Within such a conception, various novel arguments should be accepted in defense of peer-to-peer networks and other technological developments that in the current model would be discarded. For example, in the case of peer-to-peer networks, users often argue that peer-to-peer network sharing of copyright protected files increases the total number of sales of music and video products. ${ }^{8}$ In the current "information as private property" regime, such claims are only peripherally relevant to our analysis of infringement, even if empirically proven. ${ }^{9}$ However, under a scheme informed by an understanding of information ownership as a semicommons, such claims would be directly relevant to the question of whether uses were fair, and whether infringement had occurred or was facilitated by a particular technology.

The purpose of this Article is to establish that, within our perception of information as owned, such ownership is not purely private, but is instead a semicommons, and to examine further the implications of this conclusion. Part II begins the Article in earnest, discussing the peer-to-peer networking arena as an example of the private property view of information ownership in practice, and laying out the issues involved, the arguments raised, and the prizes at stake.

Part III discusses more fully the current debate over information ownership and details the nature of the debate as one fraught by notions of what is termed "purely private" ownership. Part III also discusses the normative implications this private property paradigm has on the information ownership debate.

Part IV shows what no one seems to contest: within the relevant legal framework, information is viewed as something that can be-and isowned. This section notes that the legal structures that lead to private ownership are based primarily on the perceived need to provide the incentives necessary to make information creation and distribution economically viable. ${ }^{10}$ It further lays the necessary foundation for a discussion of the dynamic relationship between common and private uses of information, and offers a description of the nature of information, both in market and non-market terms, showing that inherent elements of informationespecially its intangibility, general substitutability, ${ }^{11}$ and nature as a public

8. See Napster II, 239 F.3d at 1018.

9. See id.

10. The question of whether this perceived need is in fact accurate is beyond the scope of this Article.

11. Substitutability is used here not in the economic sense of a good that can be perfectly replaced with another good for market purposes, but rather to illustrate the notion that a user may accept different expressions of the same information based on his or her 
good-pose problems not found in other kinds of property. These problems do not undermine the conclusion that information is viewed as property in current legal doctrines, but instead highlight the differences that must be considered when thinking about information as property.

Part V advances a new framework through which information ownership can be viewed: the semicommons. The hallmark of a semicommons is the explicit recognition of a dynamic relationship between the common and private uses of semicommons property, such that their coexistence maximizes wealth to an extent not possible under either a purely common or a purely private scheme. An integral part of the maximization equation is that the benefits derived from the existence of the semicommons property scheme must outweigh the costs of prohibiting strategic behavior. Various methods-based in the legal, technological, architectural, and normative arenas - are used to prevent strategic behavior in the semicommons. Part V first evaluates the application of the semicommons theory in the context of the open fields of Medieval England as developed by Henry Smith, and then explores how information can also be viewed as a semicommons. It then discusses methods for avoiding strategic behavior for the information semicommons.

Part VI explores the ramifications of viewing property as a semicommons. Semicommons theory provides greater explanatory power in the current debate over private versus common uses of information than do other available theories. Returning to the peer-to-peer file sharing, Part VI shows by example the effectiveness of the semicommons theory.

Part VII concludes that the semicommons theory can illuminate the issues and the stakes involved in making important normative choices in ways that simply accepting private property theories cannot, and can make a substantive contribution to the ongoing debate over information ownership.

\section{TECHNOLOGICAL TENSION: PEER-TO-PEER FILE SHARING}

The case study presented here involves one particular technology, the peer-to-peer file sharing application, that allows users to connect across the Internet for the purpose of sharing files of various types. ${ }^{12}$ Internet us-

needs. That is, the information contained within the expression may be similar, and thus the varied expressions of it may all be acceptable to various users. See infra notes 51-53 and accompanying text.

12. Peer-to-peer software applications do not generally discriminate by file type, but in respect of file types are considered a neutral platform for exchange. 
ers hailed peer-to-peer as a boon because of its facilitation of the direct transfer of files in a nearly costless fashion across a decentralized platform made up of the users themselves. ${ }^{13}$ Peer-to-peer technology promised users the ability to download files from and share files with other users. The act of sharing was at once seen as expressive-users chose files to share that they valued and thought others would value-and as contributing to a community of users. ${ }^{14}$ Peer-to-peer options increased, and users joined in increasing numbers.

Peer-to-peer applications also drew the attention of the owners of the intellectual property rights to the music and video files being shared. The owners sued to stop what they viewed as the illegal distribution of files via the peer-to-peer networks, but in place of suing the individual users who were making the files available, ${ }^{15}$ they sued the peer-to-peer networks themselves. ${ }^{16}$ In one notorious case, this led to the "closing" of the peerto-peer application and the end of its usefulness to its users. ${ }^{17}$ Other peerto-peer networks responded by locating outside of the United States (ostensibly to avoid the jurisdiction of U.S. courts), and designing networks over which they allegedly had little or no control. ${ }^{18}$

13. See, e.g., LAWRENCE LESSiG, COdE AND OTHER LAWS of CyBERSPaCe (1999) (stating that "[p]eer-to-peer is the next great thing for the Internet") [hereinafter LESSIG, CODE]; see also PEER-TO-PEER: HARNESSING THE POWER OF DiSRUPTIVE TECHNOlOGIES (Andy Oram ed., 2001); Philip Agre, P2P and the Promise of Internet Equality, 46 COMM. ACM 39 (2003).

14. See Kathy Bowrey \& Matthew Rimmer, Rip, Mix, Burn: The Politics of Peer-toPeer and Copyright Law, 7 FIRST MONDAY 8 (Aug. 2002), available at http:// firstmonday.org/issues/issue7_8/bowrey/index.htmi; see also CLAY SHIRKY ET AL., 2001 P2P NETWORKING OVERVIEW: THE EMERGENT P2P PlatForM OF PRESENCE, IDENTITY, AND EDGE RESOURCES (2001); Jintae Lee, An End-User Perspective on File-Sharing Systems, 46 COMM. ACM 49 (2003).

15. In 2003, rights owners started suing individual users as well. See RIAA's Lawsuits Meet Surprised Targets, WASH. POST, Sept. 10, 2003, at E1 (describing the Recording Industry Association of America's lawsuit strategy that targeted 261 individual users).

16. See Metro-Goldwyn-Mayer Studios, Inc. v. Grokster, Ltd., 259 F. Supp. 2d 1029, 1031 (C.D. Cal. 2003); Napster I, 114 F. Supp. 2d 896, 896 (N.D. Cal. 2000).

17. See Napster IV, 284 F.3d 1091, 1091 (9th Cir. 2002); see also Brenda Sandburg, Federal Judge Plays Requiem for Napster, Shuts Down Site, LEGAL INTELLIGENCER, July 13,2001 , at 4 .

18. For example, a Dutch court recently held that Kazaa, another peer-to-peer application, was not in violation of copyright laws in operating under a model not substantially different from that of Napster. See 'Dutch Napster' Wins Reprieve, BBC NEwS, Mar. 28, 2002, at http://news.bbc.co.uk/1/hi/business/1899725.stm (last visited Mar. 25, 2003); see also Grokster, 259 F. Supp. 2d 1029, 1046 (C.D. Cal. 2003) (finding Grokster and Kazaa not liable for contributory infringement). 
Regardless of the nature of the peer-to-peer networks and the complaints raised about them, the legal action taken by those who saw themselves as the owners of the information being traded have brought what they view as an effective end to open peer-to-peer network applications. ${ }^{19}$ There are, in the information owners' views, no legitimate purposes for such applications other than to undermine ownership in information or, more specifically, to steal their property. ${ }^{20}$ The courts have viewed the disputes as involving technology that facilitates theft of private property, or property in information created by federal statute. ${ }^{21}$

Therein lies the tension. On the one hand, peer-to-peer file sharing systems have the potential to empower individuals, to provide distribution networks for individual works, expressions, creations and beliefs, and to allow all of this to occur in a decentralized and end-user controlled system. ${ }^{22}$ At the same time, information creators, owners, distributors, and

19. "Open" here is an indication of the network's non-affiliation with any particular content. There is some sign that various content-for example, information-owners are planning to launch their own peer-to-peer networks that will allow for distribution of their own content. Such systems are significantly different from systems that allow the exchange of any type of file. See Chasing the Bottleneck, RED HERRING, Oct. 15, 2001, at http://www.redherring.com/Article.aspx?f=articles $\% 2$ farchive $\% 2 \mathrm{fmag} \% 2 \mathrm{fissue} 106 \% 2 \mathrm{fc}$ atch.xml (reporting that these new peer-to-peer networks should be successful because they "borrow" end-user bandwidth and thus reduce costs for distributors).

20. See Compl. for Contributory and Vicarious Copyright Infringement, Violations of Cal. Civil Code Section 980(a)(2), and Unfair Competition at 12, A\&M Records, Inc. v. Napster, 114 F. Supp. 2d 896 (N.D. Cal. 2000) (No. C99-5183-MHP) ("Napster is not developing a business around legitimate MP3 music files, but has chosen to build its business on large-scale piracy."), available at http://news.findlaw.com/hdocs/docs/ napster/riaa/napster_complaint.pdf (last visited Dec. 7, 2003).

21. See, e.g., Grand Upright Music, Ltd. v. Warner Bros. Records, Inc., 780 F. Supp. 182, 183 (S.D.N.Y. 1991). The court in Grand Upright Music stated:

'Thou shalt not steal' has been an admonition followed since the dawn of civilization. Unfortunately, in the modern world of business this admonition is not always followed. Indeed, the defendants in this action for copyright infringement would have this court believe that stealing is rampant in the music business and, for that reason, their conduct here should be excused. The conduct of the defendants herein, however, violates not only the Seventh Commandment, but also the copyright laws of this country.

Id. (citations omitted). But see Dowling v. United States, 473 U.S. 207 (1985) (holding that the shipping of "bootlegged" records did not constitute shipping stolen goods in violation of federal law).

22. See generally Yochai Benkler, From Consumers to Users: Shifting the Deeper Structures of Regulation Towards Sustainable Commons and User Access, 52 FED. COMM. L.J. 561 (2000) [hereinafter Benkler, From Consumers to Users] (arguing that 
publishers accuse peer-to-peer networks of serving primarily to undermine their property rights. ${ }^{23}$

The potential of the peer-to-peer design should be apparent: it enables users to connect with each other, allows small creative artists to distribute their works outside of the traditional channel of distribution controlled by large, powerful media corporations. ${ }^{24}$ It also provides an avenue for distributing, sharing, or collaborating in text works, whether traditional novels, scientific research, or new categories of works. ${ }^{25}$ The technology has the ability to enhance autonomy by giving individuals greater control over their own lives, creativity, and choices.

But in practice, the technology took a different turn. Users of early peer-to-peer file sharing networks chose to share two primary types of files: audio and video. In general, these files were converted or extracted from media files held by peer-to-peer participants. ${ }^{26}$ Thus, users were distributing files on which others held enforceable copyrights.

"[t]he emergence of the digitally networked environment makes possible the development of a robust, open social conversation in which all can participate as peers").

23. See, e.g., Howard P. Goldberg, Note, A Proposal for an International Licensing Body to Combat File Sharing and Digital Copyright Infringement, 8 B.U. J. SCI. \& TECH. L. 272, 273 (2002) ("Computer users, through the digital file sharing of copyrighted works, are able to infringe upon a copyright holder's exclusive rights."). To combat peerto-peer networks' alleged encroachment on their rights, information owners have developed DRM systems. See generally Lionel S. Sobel, DRM as an Enabler of Business Models: ISPs as Digital Retailers, 18 BERKELEY TECH. L.J. 667 (2003) (describing DRM technologies and their implications). These systems are designed to preclude the easy copying of digital works and are themselves protected by a legal regime designed ultimately to ensure protection for the underlying creative works. See 17 U.S.C. $\S 1201$ (2000). DRM systems combine software or code protection with hardware protection. Digital Video Disks ("DVDs"), for example, use a system called Content Scrambling System ("CSS") to decode the video and audio data encrypted on the disk. See Universal City Studios, Inc. v. Corley, 273 F.3d 429, 436 (2d Cir. 2001). DVD player manufacturers must license the right to implement CSS on their systems, and in this way content manufacturers can ensure that media content is protected. See id. at 436-37.

24. See, e.g., Hassan M. Fattah, P2P: How PeER-To-PeER Technology Is RevolutionizInG THE WAY We Do Business (2002); see also MichaEl MiLleR, DisCOVERING P2P (2001).

25. See Upgrading the Internet, ECONOMIST, Mar. 24, 2001, at 32. The newest incarnation of the Internet, known as Internet2, is designed to facilitate the same types of collaborative efforts that peer-to-peer applications also promised to bring. Id.

26. Audio files, for example, can be easily "extracted" from audio compact discs by computer software applications that convert the CD audio wave files to MP3 format. MP3 files are smaller in size than audio wave files, thus they are easier to send over networks and store on computer hard drives. Video files can either be "captured," where users attach a VCR to their computer and "record" the analog output of the video as a 
Initially, this lead to very few problems, as peer-to-peer technology was flying largely under the radar of the major copyright holders. ${ }^{27}$ However, the number of peer-to-peer end users and the number of technological options for file-sharing increased. In the late 1990s, artists and publishing companies began launching attacks on file-sharing and started public relations campaigns that appealed to users' ethical and legal consciences to refrain from copyright infringing activities. ${ }^{28}$

Eventually, when the publishing and distributing industries, as well as some elements of the creative community, ${ }^{29}$ felt they were losing the battle, or more particularly, losing business and sales to online peer-to-peer sharing, they began to bring lawsuits against the networks themselves. One of the earliest lawsuits sought an injunction against Napster, a successful peer-to-peer application, requesting that the court shut down the company's network operations. ${ }^{30}$ The District Court issued the injunction. ${ }^{31}$

Napster, in danger of bankruptcy if the injunction was allowed to stand, appealed to the Ninth Circuit. ${ }^{32}$ As it had below, Napster argued that its users were not direct infringers, and, in the alternative, even if they were, Napster was not liable under copyright doctrine for assisting or failing to stop its users' infringing activities. ${ }^{33}$ The Ninth Circuit, however, agreed largely with the analysis adopted by the District Court. Specifically, the court found that by trading copyrighted files over the Internet, Napster users were directly infringing the protected rights of the record companies. $^{34}$

digital file, or "ripped," where users extract digital files from DVDs or other forms of digital video.

27. See Matthew Fagin et al., Beyond Napster: Using Antitrust Law to Advance and Enhance Online Music Distribution, 8 B.U. J. SCI. \& TECH. L. 451, 457-64 (2002) (detailing the background and history of peer-to-peer development and the content owners' reaction to it).

28. Id.

29. Not all artists felt that file-sharing was a negative. See Stephanie Green, Reconciling Napster with the Sony Decision and Recent Amendments to Copyright Law, 39 AM. Bus. L.J. 57, 65 (2001) ("Artists who support Napster see the potential for Napster's method of music distribution which gives more return to the artist directly by eliminating the middleman and the stranglehold of the big record labels.").

30. Napster I, 114 F. Supp. 2d 896, 896 (N.D. Cal. 2000).

31. Id. at 927.

32. Napster II, 239 F.3d 1004, 1004 (9th Cir. 2001).

33. Id.

34. Id. at 1014 . 
Napster raised the fair use defense on its users' behalf under three separate theories, all of which proved unsuccessful. ${ }^{35}$ The first, or "sampling," theory was based on the notion that users download the music in an effort to decide whether to buy it. ${ }^{36}$ The second, or "space-shifting," theory was based on the idea that users who already own a licensed copy of the recording would download the MP3 version from Napster so as to avoid the need to rip the audio track themselves. ${ }^{37}$ The third, or "permissive distribution," theory was based on the idea that some artists and recording companies have decided to make their works available online and without the requirement of a purchased license, and thus redistribution is implied under the companies' chosen method of distribution. ${ }^{38}$

The court rejected the first two of Napster's fair use theories, and found the third irrelevant for purposes of the record companies' action. ${ }^{39}$ In rejecting the first two theories, the court reviewed each of the four statutory elements of fair use: the purpose and character of the use, the nature of the copyrighted work, the amount and substantiality of the portion used, and the effect of the use on the potential market for the work or the value of the work. ${ }^{40}$

For our purposes, the Ninth Circuit's analysis of the last statutory factor is the most relevant. In discussing the effects of Napster users' activities on the market for the plaintiffs' works, the District Court had discounted but not excluded evidence offered by Napster in the form of an expert opinion that Napster users' activity was beneficial to the recording

35. Id. at 1019 .

36. Id. at 1018 .

37. Id. at 1019 .

38. Id.

39. Id. (holding that the permissive distribution claim was irrelevant because the plaintiff record companies were not alleging that such permissive distribution violated their rights under copyright law, and thus any permissive distribution was not relevant to their claims).

40. Id. at 1014-15. The Ninth Circuit agreed with the District Court's determination that Napster users' activities militated against a finding of fair use under each of the four tests. Id. First, under the "purpose and character" test, the courts found that the nature of the users' activity was not transformative, but rather was a mere "retransmission [of the original works] in another form." Id. at 1015. Furthermore, although the users were generally not making money from each other, their use was commercial. Id. Second, both courts found that the works were creative and were thus the exact type of works that copyright is intended to protect. $I d$. at 1016 . Third, users making complete copies of copyrighted sound recordings. Id. Finally, users were impairing the market as to sales of traditional sound recordings, and were also displacing the market for the copyright holders in the digital realm. Id. at 1016-17. 
industry. ${ }^{41}$ Even without the derogation of the defendant's evidence, however, the Ninth Circuit noted that "lack of harm to an established market cannot deprive the copyright holder of the right to develop alternative markets for the works." ${ }^{, 2}$ Note that, in effect, this makes nearly any evidence of benefit to the market for an information product irrelevant where it occurs in a market in which the information owner has not already established itself, or possibly even where it has. In such a case, the common use that has been established prior to the private owner either seeing or taking advantage of a new market for its goods acts as a "barrier" to the owner's entering the new market. ${ }^{43}$ In short, the court noted that benefits to the record companies from the common use would not be sufficient to bring the use within the fair use provisions of copyright law. According to the Ninth Circuit,

[t] The District Court ... correctly noted that 'any potential enhancement of plaintiff's sales ... would not tip the fair use analysis conclusively in favor of defendant.' We agree that increased sales of copyrighted material attributable to unauthorized use should not deprive the copyright holder of the right to license the material. ${ }^{44}$

Having determined that the Napster users' infringing activities were not protected by the fair use defense, the Ninth Circuit upheld the District Court's finding that Napster was potentially liable for both contributory and vicarious copyright infringement. This finding was based on the fact that Napster knowingly provided the method by which files were traded and had some ability to police its own system which it refused to fully exercise. While the potential for liability was sufficient to uphold the preliminary injunction, the Ninth Circuit did modify the constraints of the injunction, though not in a way significant enough to allow Napster to continue to operate as it had in the past.

On remand, the District Court modified its injunction to bring it in line with the Ninth Circuit's decision, and required Napster to remove files from its search index where it received "reasonable notice" of the existence of infringing files. The District Court also adopted a "zero tolerance" requirement, whereby Napter's failure to stop all trading of files "owned" by others would not be excused. After three months of court-administered monitoring, the District Court found Napster in violation of the modified
41. Id. at 1017 .
42. Id.
43. Id.
44. Id. at 1018 . 
order, and in accordance with its zero tolerance policy, directed it to shut down. The Ninth Circuit upheld the shutdown order on appeal, accepting explicitly the District Court's adoption of the zero tolerance requirement.

The Napster case is a clear example of courts and litigants viewing information protected by copyright as private property. Fair use is ultimately the use of someone else's property, a notion that colors and channels debate and legal decisions regarding use of information. Peer-to-peer software has the potential to invigorate and support a variety of new methods of production and distribution of digital goods, and in so doing to invigorate and empower creative people the world over. But because of how we view information ownership, because our conception is one that pits private users against common users, where private users are expected to seek compensation for each and every use of their "property" as such ${ }^{45}$ Napster was ultimately shut down by court order. ${ }^{46}$ The only way that the Napster system could have continued in operation was if it was modified to operate according to the needs, not of its common users, but of the owners of the information being traded via its facilities. The District Court's adoption and the Ninth Circuit's approval of the zero tolerance requirement made this clear.

\section{THE CURRENT DEBATE: THE TENSION BETWEEN PRIVATE AND COMMON USES}

Over time, different types of goods and means of production have been the primary focus of market transactions and exchanges, and property law has often been the center of attention in terms of distribution of wealth. ${ }^{47}$ Each era's economic engines have been fueled by different resources and production methods, and ownership of those resources and methods has been a political and cultural issue of great importance. ${ }^{48}$

45. This expectation is not somehow an imposed or unreasonable expectation. Market based systems expect property owners to seek remuneration, but that expectation is not the reason for owners' actions. Markets base their expectations on owners' actual desires. In other words, owners seek remuneration because they desire remuneration, not because it is expected of them.

46. See Napster IV, 284 F.3d 1091, 1096 (9th Cir. 2002); see also Brian Garrity, Media Giant's Support Of Napster 'Vicarious Infringement', BILLBOARD, Mar. 1, 2003, at 7 (reporting that one of Napster's funders, the Bertelsmann corporation of Germany, is now being sued by a group of music publishers who allege it is also vicariously liable for Napster's actions).

47. See, e.g., Karl Marx \& Frederick Engels, The Communist Manifesto (A.J.P. Taylor ed., Samuel Moore trans., 1967).

48. For example, Rousseau touches on this theme in his second Discourse on Inequality: "[A]ll the inequality which now prevails owes its strength and growth to the de- 
In today's advanced capitalist economies, markets are becoming more and more focused on information creation and distribution. Information is the primary resource in the information economy; its production is the main focus of members of the information society and its ownership is the driving force in the creation and continuation of wealth. ${ }^{49}$ It is unsurprising that the nature of the property scheme that underlies the shift to the new economy should become a subject of dispute, especially as its establishment and continued development are certain to affect the distribution of wealth in society, both in postindustrial nations and throughout the world. ${ }^{50}$

There are a number of questions within this setting, however, that are different in nature and degree from those that have been asked in past generations about the ownership of resources and production methods. The nature of information is significantly different from the nature of past commodities: it is intangible, non-rival, and non-exclusive. In many cases, it is also substitutable: one piece of information may be "replaced" by another similar one. ${ }^{51}$ Given this, the legal schemes and policy discussions that surround information must also be different. ${ }^{52}$ With the growth over the past ten years of large-scale and nearly costless methods of informa-

velopment of our faculties and the advance of the human mind, and becomes at last permanent and legitimate by the establishment of property and laws." JEAN-JACQUES ROUSSEAU, The Social ConTract and Discourses 238 (G.D.H. Cole trans., J.M. Dent 1913); see also CONSTANTIN SONIN, PRIVATE PROTECTION OF PROPERTY RIGHTS, INEQUALITY, AND ECONOMIC GROWTH IN TRANSITION ECONOMIES (Econometric Soc'y World Congress, Contributed Paper No. 1300, 2000); Timothy Frye \& Andrei Shleifer, The Invisible Hand and the Grabbing Hand, 87 AM. ECON. REV. 354 (1997).

49. See Trevor Haywood, INFo-RICH-INFo-Poor (1995); Michael W. Hill, The IMPACT OF INFORMATION ON SOCIETY (1999); DAVID LYON, THE INFORMATION SOCIETY (1988); Nat'l ACAD. SCI., The Digital Dilemma: Intellectual Property IN THE Information Age (2000); DAVID WeINBERger, SMALl PieCES LOOSEly JoINed: A UNIFIED THEORY OF THE WEB (2002).

50. See, e.g., COMM'N ON Intell. Prop. Rights, Integrating Intellectual PROPERTY AND DEVELOPMENT POLICY 25-26 (2002), http://www.iprcommission.org/ graphic/documents/final_report.htm (warning that developing countries should not adopt Western strength IP protection).

51. This does not mean information forms are substitutable in the economic sense, but rather that the meaning contained within information may be transmitted or continued without the need for or use of the original expression of that information.

52. See, e.g., LaWrence Lessig, The Future of Ideas: The Fate of the CoMMONS IN A CONNECTED WORLD (2001) [hereinafter LESSIG, FUTURE OF IDEAS]; MICHAEL PERElMAN, STEAL THIS IdEA (2002); MARK Rose, AUthors AND OWNERS: THE INVENTION OF COPYRIGHT (1993). 
tion distribution, questions of ownership and control have dramatically increased in importance. $^{53}$

Within these debates, the ownership of information is often treated as a given. ${ }^{54}$ According to this view, information is clearly subject to private ownership; information is property. ${ }^{55}$ This perception pervades discourse on information issues. Efforts to define the importance of information policies accept the notion of private ownership of information, and seek to limit the extensions of this ownership within an effort that is consistent with past attempts to control privatization of public goods. ${ }^{56}$

These efforts, and the overall ownership debate, are based too heavily on a conception of private property. By adopting this perspective, we focus too much attention on the burdens that common and private uses of information place on each other, while failing to acknowledge the significant benefits that result from the interaction between both types of use. The reason is clear: burdens and benefits resulting from the dynamic interaction between common and public information uses do not easily fit within traditional notions of private property. In a more traditional property scheme, the private property owner has the right and, indeed, the eco-

53. See Jorge ReInA SCHEMENT \& TERry CuRtis, Tendencies and Tensions of THE INFORMATION AGE: THE PRODUCTION AND DISTRIBUTION OF INFORMATION IN THE UNITED STATES (1995).

54. See, e.g., Andrew Beckerman-Rodau, Are Ideas Within the Traditional Definition of Property?: A Jurisprudential Analysis, 47 ARK. L. REV. 603 (1994) (concluding that common law idea protection, trade secret law, and patent law are all property based regimes predicated on the recognition of property rights in ideas).

55. See, e.g., United States v. Wang, 898 F. Supp. 758 (D. Colo. 1995) (holding that, in contrast with the Supreme Court finding that the National Stolen Property Act did not apply to intangible property so as to bring copyright infringement within that Act, the federal wire fraud statute did apply, as it contained no requirement that the property in question be "tangible"); see also United States v. Riggs, 739 F. Supp. 414 (N.D. Ill. 1990) (holding that even if wire fraud statute required tangibility, information contained in a computerized list qualifies for that status).

56. For example, during debate on the Senate floor prior to adoption of the DMCA, Senator Strom Thurmond stated: "This legislation implements the WIPO treaties to help protect the property rights of the creative community in our global environment." 144 CONG. REC. S11888 (daily ed. Oct. 8, 1998) (statement of Sen. Hatch). Senator Hatch, during the same debate, stated, "The WIPO treaties and the DMCA will protect the property rights of Americans in their work as they move in the global, digital marketplace, and, by doing so, continue to encourage the creation of new works to inspire and delight us and to improve the quality of our lives." $I d$. at 11889. 
nomic imperative, to undertake proper development. Private property is thus efficiency's answer to the tragedy of the commons. ${ }^{57}$

Ostensibly responding to the need for a system of incentives to encourage the creation of information products, legislative enactments and court decisions have expanded the private use rights of information creators. ${ }^{58}$ Information owners have praised these actions as providing further incentives for creation of information to fuel the information economy. Common use advocates have decried them as part of an attempt to "enclose" what is and should be the commons in the name of gaining profits. ${ }^{59}$ The debate is ongoing, and has come to a head in lawsuits such as Eldred v. Ashcroft ${ }^{60}$ in which the plaintiff challenged Congress's authority to extend the length of both prospective and retrospective protection for works covered under the copyright law.

On the one side of this debate are scholars, inventors, writers, and creators who question the establishment of further protection of individual ownership of works, inventions, and creations. ${ }^{61}$ On the other, those who believe privatization of information is simply another proper step in reaching the same economic efficiency for information as we have for other commodities. $^{62}$ The common use literature makes the case not that "information longs to be free, ${ }^{, 63}$ but that it is necessary and important that

57. See Garrett Hardin, The Tragedy of the Commons, 162 SCI. 1243 (1968); see also ELINOR OSTROM, GOVERNING THE COMMONS: THE EVOLUTION OF INSTITUTIONS FOR COLLECTIVE ACTION (1990).

58. See, e.g., Digital Millennium Copyright Act ("DMCA"), Pub. L. No. 105-304, 112 Stat. 2860 (1998) (codified in scattered sections of 17 U.S.C., 28 U.S.C., and 35 U.S.C.); Sonny Bono Copyright Term Extension Act, Pub. L. No. 105-298, 1125 Stat. 2827 (1998) (codified in scattered sections of 17 U.S.C.).

59. See James Boyle, The Second Enclosure Movement and the Construction of the Public Domain, Conference on the Public Domain (Nov. 2001), at http://www.law.duke. edu/pd/papers/boyle.pdf (last visited Feb. 24, 2003); see also David Lange, Recognizing the Public Domain, 44 LAW \& CONTEMP. PrOBS. 147, 150 (1981).

60. 537 U.S. $186(2003)$.

61. See, e.g., James Boyle, Shamans, Software AND SPleEns: Law AND THE CONSTRUCTION OF THE INFORMATION SOCIETY (1996); LESSIG, FUTURE OF IDEAS, supra note 52; Yochai Benkler, Through the Looking Glass: Alice and the Constitutional Foundations of the Public Domain, 66 LAW \& CONTEMP. PROBS. 173 (2003); Jed Rubenfeld, The Freedom of Imagination: Copyright's Constitutionality, 112 YALE L.J. 1 (2002).

62. See, Brief of Amici Curiae American Intellectual Property Law Association at 10-16, Eldred v. Ashcroft, 537 U.S. 186 (2003) (No. 01-618) (arguing that the Sonny Bono Copyright Term Extension Act provides authors the benefit of their copyright bargain and encourages the preservation, dissemination and exploitation of older, valuable works).

63. This is one of the early cries of hackers and other activists on the Internet, and is more rhetorical hyperbole than actual argument. 
current and future generations have access to and use of the store of knowledge, and even particular expressions of that knowledge. ${ }^{64}$ Those who view themselves as the owners of particular expressions counter that these things are their property, and in line with the concepts of property, it is entirely appropriate to provide extra, extended, or greater protection where doing so further extends the perceived economic benefits of the creative process. $^{65}$

Two macro-level perspectives are generally identifiable for information ownership: one that focuses on private ownership (and thus private control) of information in models drawn from property theory, ${ }^{66}$ and one that focuses on common ownership (and thus common control) of information. ${ }^{67}$ The paradigm is well established that common use exists at the expense of private use. In fact, the need for private ownership of the commons grows out of well established property conceptions. The two sides here could even be described as battling over information ownership, each setting out essentially opposite positions designed to show how the engagement of the legal structures in certain ways will affect societal and market development, as well as individual autonomy, freedom, and satisfaction. The positions are, for the most part, diametrically opposed: private use proponents advocate more private control, longer ownership terms, and more private rights in the information they claim, while common use proponents advocate less private control, shorter ownership terms, and more common use rights in information generally.

This is not an indication that each side seeks the "end" of the other. There is some acknowledgment in most of the common-advocacy literature that some private incentives might be necessary for information creation to occur, and in the private-advocacy literature that some common use is acceptable. But on the whole, the two sides are in conflict over the balance that is to be struck between the uses, and the uses themselves are viewed as antagonistic.

In other words, these debates are based on the notion that common and private uses of information are inherently and primarily conflicting. For example, providing longer lengths of time to copyright protection for information creators removes important information from the information commons. One use "takes from" the other. There is little acknowledgment

64. See, e.g., LESSIG, FUTURE OF IDEAS, supra note 52.

65. See Brief of Amici Curiae Recording Artists Coalition, Eldred v. Ashcroft, 537 U.S. 186 (2003) (No. 01-618) (arguing that the term limits in the Sonny Bono Act provide incentives both to current artists and to their heirs).

66. See Becker-man-Rodau, supra note 54.

67. See Benkler, From Consumers to Users, supra note 22. 
or explicit discussion of the dynamic interaction of private and common uses. Instead, the uses are at war; gain by one is its pure gain and the other's pure loss.

This framework of antagonism is entirely consistent with historical private use versus common use discussions. Where land was used for grazing in the traditional commons, private property displaced the commons and sought to make more efficient and sustainable use of it. ${ }^{68}$ The need to strike a proper balance between common and private uses is a recurring theme, and the current debate seems to fall neatly into existing paradigms of property and use rights. ${ }^{69}$ In fact, the paradigm appears to be so well established that some scholars have begun to attempt to chip away at the use of property metaphors in the information arena in the hopes of recasting the argument in a different light. ${ }^{70}$

Private use arguments are most often based on the perceived need to enhance existing incentives to create information and, more precisely, to provide greater economic advantages for engaging in such creation. While the position is also sometimes grounded in Lockean notions of property rights flowing from individual effort, the economic incentive arguments generally carry the majority of the weight in policy and legal decisionmaking. ${ }^{71}$ Viewed in any light, the private use perspective on information ownership is based on traditional notions of real and personal property. In other words, it is based on ownership of some "thing." 72

68. See Hardin, supra note 57 , at 1243-48.

69. See Boyle, supra note 59.

70. See, e.g., Dan Hunter, Cyberspace as Place and the Tragedy of the Digital Anticommons, 91 CALIF. L. REV. 439 (2003) (arguing that the "place" metaphor used in discussing and referring to the Internet has colored our perceptions and led us to accept property based conceptions of information, and raising important issues as to the way in which metaphors affect law); see also STEPHEN L. WINTER, A CLEARING IN THE FOREST: LAW, LIFE, AND MIND (2001).

71. There is an important distinction to be made here between using Lockean notions when seeking legislative and judicial changes and using Lockean notions in relation to the rhetoric of public education about rights in information. The large industrialized apparatus that makes up the core of the new information infrastructure generally relies heavily on notions of efficiency and incentive in arguing for more private control over information, but sings a more moral tune when publicizing the rights it has obtained in the legislative and judicial fora.

72. What a "thing" is in this regard is an interesting question. If it is a physical thing, then intellectual property is not property at all. But many of us would agree that a sound is a "thing," though it is intangible and temporary. For our purposes here, we will include both the tangible and intangible as "things." See Henry Lanz, The ThingConception in the Middle Ages, 29 PHIL. REV. 226, 226 (1920) ("Generally speaking, there are as many thing-conceptions as there are types of civilisation and culture; every 
For their part, common use advocates dispute not only the proper amount of private protection needed to properly stimulate the creation of information, but also often question the idea that incentives are necessary at all. ${ }^{73}$ Even when begrudgingly accepting the private incentives argument, common use advocates seek greater liberty for users of information, including the rights to alter, to derive new works from existing ones, and to comment on and critique the works of others through satire or parody. The concept of the public domain or of the commons in information is illustrative of this point.

epoch has a theory of objectivity of its own."); R.W. Sellars, A Thing and its Properties, 12 J. PHIL. PSYCHOL. \& SCI. METHODS 318, 318 (1915) ("Things, for common sense, are perceived or at least capable of being perceived and are known to be independent of the perceiver so long as he does not operate upon them by means of his body."); Leslie Stevenson, On What Sorts of Thing There Are, 85 MIND 503 (1976) (laying out some of the ontological complexities of discussions of things). That intangibility is not problematic to property theory is not without disagreement; see, e.g., J.E. PENNER, THE IDEA OF PROPERTY IN LAW (1990) (arguing that "thingness" is particularly important to property theory).

73. This is not necessarily a new idea. In the 1830 s, William Leggett wrote: If the principle of copyright were wholly done away, the business of authorship, we are inclined to think, would readily accommodate itself to the change of circumstances, and would be more extensively pursued, and with more advantage to all concerned than is the case at present. It is very much the fashion of the day to deride and decry cheap publications. We are not of the number who can join in the censure. The great good which the invention of printing originally effected, was to diffuse literature, and make books accessible to myriads, who were precluded from them before, by reason of the enormous prices at which manuscript copies were sold. ... . It is spreading literature over the entire land. .... It is penetrating with it into every nook and corner of society. It is offering its golden fruits, ay, richer than gold, to the poor and ignorant, as well as to the rich and educated. It is awakening millions of human beings to a sense of their birthright; to acknowledge that they are God's creatures, and not beasts that perish. ... . If there were no copyright laws, all literature would take a cheap form, and all men would become readers. . . . Instead of an edition of two, or three, or five thousand copies, which never constitute, as a general rule, the maximum of a popular author's success, twenty, thirty, and perhaps a hundred thousand would be readily disposed of. Let us withdraw our attention, for an instant, from a contemplation of the interests of authors, to consider those of mankind at large. Who can fail to see how vastly the general benefit would be promoted? ... . [I]f knowledge is power, what a vast influence it would exercise in the counsels of nations, and in directing the destinies of mankind!

William LEgGETT, DEMOCRATICK EDITORIALS: ESSAYS IN JACKSONIAN POLITICAL ECONOMY 394-95 (Lawrence H. White ed., 1984) (essays originally published beginning in 1834). 
Just as the concept of information as subject to private ownership has been bound up in land and physical property analysis, so has the common use view of information. Discussions of the "information commons" are rife in common use literature, though the literature does not uniformly define the public domain. One of the most accepted definitions of the public domain is information that is available for use without restriction, ${ }^{74}$ while another expands the definition to "the range of uses of information that any person is privileged to make absent individualized facts that make a particular use by a particular person unprivileged." 75 Another definition would allow for information to be considered as part of the commons, even if there is a fee, so long as the fee is applied without discrimination. ${ }^{76}$

Only recently has the perception of the information commons begun to move from an asset-based understanding to a use-based understanding. ${ }^{77}$ The shift is important in that it coincides with the argument made here that information ownership is not based in traditional regimes of asset-based property rules that provide protection for an entire "thing," but rather is based on the notion of use of information. While the newer understanding is clearly more in line with the theory of the information semicommons, it is still based on a primarily antagonistic relationship between the private and common uses, and in that way continues the "information as private property" conception that has been the primary theory of information ownership so far.

Within the debate over the balance between private and common uses of information, it is clear that both sides are constrained within the private use/common use dichotomy that has evolved in the landed property arena. While some commentators question the validity of the application of property principles to information due to the differences in the nature of infor-

74. See Jessica Litman, The Public Domain, 39 EMORY L.J. 965, 968 (1990).

75. See Yochai Benkler, Free as the Air to Common Use, 74 N.Y.U. L. REv. 354, 362 (1999) [hereinafter Benkler, Free as the Air]. Note the difference between the Litman and Benkler definitions. Litman's definition is more narrow, in that it only applies to information that is available for use by all people, and thus includes only unprotected information as a whole. Benkler's definition includes information that any person can use, and thus includes information subject to protection, but which may also be subject to common use. Benkler's definition includes uses protected by fair use and other copyright defenses, while Litman's does not. For purposes of the semicommons, Benkler's definition is closer to our understanding of the nature of information in that it recognizes explicitly that both private and common uses of information can occur contemporaneously.

76. See LESSIG, FUTURE OF IDEAS, supra note 52.

77. See Benkler, Free as the Air, supra note 75. 
mation and property, ${ }^{78}$ the point of this Article is not that the property paradigm within which the discussion is taking place is faulty in treating information as property, ${ }^{79}$ but that it is too limited in its scope.

Our understanding of property need not be limited to a choice between private and common uses; it can be both at the same time. This is not true in every case, and it need not always be true in relation to all property. But when it is true, or when it must be true-as we shall see is the case with information ownership-the decision-making process in relation to it must be different from that relating to property that is subject either to private or common use, or that is subject to a tug-of-war between the two uses. This Article details the extent of this difference, along with its implications.

\section{THE INFORMATION OWNERSHIP QUESTION}

\section{A. Information}

Before delving into the structure of information ownership, we must first define what is meant by information. The literature on intellectual property and property rights in information bypass this question entirely, even when it is apparent that the notion of information-broad or narrow-could have a distinct effect on the analysis undertaken and the conclusions reached. ${ }^{80}$

Traditional notions of information include the concept of knowledge. For example, the Oxford English Dictionary defines information as "[k]nowledge communicated concerning some particular fact, subject, or event; that of which one is apprised or told." ${ }^{81}$ Similarly, the American Heritage Dictionary of the English Language defines information as "[k]nowledge derived from study, experience, or instruction." 82

78. See Pamela Samuelson, Information as Property: Do Ruckelshaus and Carpenter Signal a Changing Direction in Intellectual Property Law?, 38 CATH. U. L. REV. 365 (1989) (examining the change in paradigm from one that views information as not covered by concepts of property to one that views information as covered by concepts of property); see also Douglas G. Baird, Common Law Intellectual Property and the Legacy of International News Service v. Associated Press, 50 U. CHI. L. REV. 411 (1983) (arguing that freedom of information is commonplace for intellectual property law).

79. On this question the author need not, and does not, express any opinion.

80. See, e.g., Benkler, Free as the Air, supra note 75 (arguing that enclosure of the public domain in information is occurring to the detriment of First Amendment principles, but not defining information).

81. OXFORD ENGLISH DICTIONARY 944 ( $2 \mathrm{~d}$ ed. 1989).

82. AMERICAN HeRITAGE Dictionary OF THE ENGLish LANGUAGE 899 (4th ed. 2000). 
Not every conception of information, however, focuses on knowledge. In 1948, Claude Shannon adopted a definition for information designed to aid the mathematical understanding of information transmission in a communicative system. ${ }^{83}$ For Shannon, information is part of a mathematical function of uncertainty and is defined as anything that lowers uncertainty. ${ }^{84}$ This definition is quantitative in nature: Shannon was concerned with how much information was transferred in communication. This definition is most relevant to disciplines concerned with communication of information rates.

Richard Losee went beyond Shannon's definition and attempted to develop a discipline-independent definition of information. ${ }^{85}$ Losee counseled that we must be careful not to be overly restrictive in our initial definition of information and warned against imbuing a definition of information with requirements of understanding, knowledge, lack of repetition, or other more particular requirements. ${ }^{86}$ While such requirements may be useful in inquiring how knowledge is developed, transmitted or understood, they mostly serve to artificially restrict broader inquiry, such as that undertaken here. Where one is unconcerned with the specific content of the information at issue, or even the ability to convey a particular message, a broader definition is more appropriate.

Losee's domain-independent definition of information emphasizes this generality: "Information is produced by all processes and it is the values and characteristics of the process's output that are information." that this definition is not concerned with the "truth" or "falsity" of information - the output characteristics convey information even if that information is not true.

83. Claude E. Shannon, A Mathematical Theory of Communication, 27 BeLl SyS. TECHNICAL J. 379 (1948)

84. Id.

85. Robert M. Losee, A Discipline Independent Definition of Information, 48 J. AM. SOC'Y FOR INFO. SCI. 254 (1997).

86. Id. This is not to say such definitions are useless or wrong, but rather that they are more limited in their usefulness. See, e.g., State v. Green, 493 So. 2d 1178, 1184 (La. 1986) (focusing on the idea that information is knowledge: "In the context of the facts now under consideration it is clear the 'information' sought by the state from Walsh was his knowledge of Green's possession of the gun prior to its surrender to the police authorities.") (emphasis original). Considering the definition of information within certain domains-quantification for Shannon or information as knowledge for the court in State v. Green - is certainly appropriate, but does not necessarily leave us with a definition that is appropriate for other uses. Thus we search for a broader and more inclusive definition.

87. Losee, supra note 85 , at 256. 
For Losee's purposes, anything that happens or occurs that yields some characteristic or value produces information. We perceive the characteristic or value as information, but there is no need for actual perception for the creation of information. It is sufficient that the characteristic is capable of such perception. Thus, all processes yield information. What we do with that information-qualify it, quantify it, categorize it-is up to us. But, according to Losee, we do not need to decide whether something is information because any characteristic constitutes information.

However, for our purposes less of a focus on the process by which information comes into being may be warranted. Theories of memetics also provide useful conceptions of information that focus less on the creation process. In his book The Selfish Gene, Richard Dawkins argued that genes are not the only things that replicate and evolve. ${ }^{88}$ Culture also evolves through the transfer of memes. Dawkins's meme, a unit of information, is a measurement of convenience, a "piece" of information that can stand alone for an idea or cultural phenomenon. According to Dawkins, "[e]xamples of memes are tunes, ideas, catch-phrases, clothes fashions, ways of making pots or of building arches." 89 Meme theory provides a way of thinking about the conveyance of information. Memes exist at many levels, and may combine to make other memes. ${ }^{90}$

These three ways of defining information-knowledge, output characteristics, memes-all have some relationship to our understanding of information, but none directly defines its contours. Given that here we are considering information ownership, we will define information as any thing ${ }^{11}$ that might be acted upon based on its content. The "thing" need not be tangible, but might be a sound, a gesture, or even a momentarily existing arrangement of clouds; each of these has the potential to convey meaning. ${ }^{92}$

We must define information broadly so that we can understand the implications of providing a property scheme for the ownership of information. If we define information narrowly, we begin only within a subset of

88. RichaRd DaWkins, The SElfish Gene 189-201 (2d ed. 1989).

89. Id. at 192.

90. Id. at 195-96.

91. The separation between "any" and "thing" here is not accidental; it allows for the emphasis on the idea that for information to be owned, it must be in existence in some form, though the form chosen is not a limiting measure for our purposes. For a more complete discussion of the "thinghood" of information, see infra notes 96 to 108 and accompanying text.

92. See, e.g., State v. Fjermestad, 791 P.2d 897, 901-02 (Wash. 1990) ("[W]e conclude that the term 'any information' as used in RCW 9.73.050 includes visual observations as well as assertive gestures."). 
information ownership, and generalizing our conclusions to the broader range of information ownership becomes difficult. Note that the choice of definition has immediate implications for this discussion. Given the broad nature of the definition, it is unlikely that all information could ever be owned, regardless of reductions in transaction costs, market failure, or uncertainty. This point will have implications for the theory developed later.

The definition adopted here is consistent with Losee's conception of information as the outcome of any process. But rather than focusing on the creation of the output characteristic (the information), it focuses on the characteristic or the thing created itself. ${ }^{93}$ The definition is not limited to those things that are actually acted upon because of their content (for example, that actually reach a human's senses and ultimately, her conscious awareness) but includes any thing that has the potential to be acted upon because of its content.

The adopted definition of information is also not limited in size, scope, or content. As with memes, one "piece" of information may well be made up of other "pieces" of information, just as one meme may be made up of other memes. ${ }^{94}$ The whole and its component pieces are all information. ${ }^{95}$

93. See also ANDREAS GÜNTHER, ProdukTHAFTUNG FÜR INFORMATIONSGÜTER: VERLAGSERZEUGNISSE, SOFTWARE UND MULTIMEDIA IM DEUTSCHEN UND USAMERIKANISCHEN PRODUKTHAFTUNGSRECHT (2001) (Translation assistance provided by Meike A. Heverly) (discussing various definitions of information, including an object oriented definition).

94. One example from Dawkins's exposition of memes is instructive in this sense:

So far I have talked of memes as though it was obvious what a single unit-meme consisted of. But of course that is far from obvious. I have said a tune is one meme, but what about a symphony: how many memes is that? Is each movement one meme, each recognizable phrase of melody, each bar, each chord, or what?

I appeal to the same verbal trick as I used in Chapter 3. There I divided the 'gene complex' into large and small genetic units, and units within units. The 'gene' was defined, not in a rigid all-or-none way, but as a unit of convenience, a length of chromosome with just sufficient copying-fidelity to serve as a viable unit of natural selection. If a single phrase of Beethoven's ninth symphony is sufficiently distinctive and memorable to be abstracted from the context of the whole symphony, and used as the call-sign of a maddeningly intrusive European broadcasting station, then to that extent it deserves to be called one meme. It has, incidentally, materially diminished my capacity to enjoy the original symphony.

DAWKINS, supra note 88, at 195-96.

95. But see Piper \& Marbury v. U.S. Postal Serv., No. 99-2383, 2001 WL 214217, at *14 (D.D.C. Mar. 5, 2001) ("While contracts may certainly contain information, such as the price of the goods being sold, the entire contract ... itself cannot qualify as 'infor- 
This does not require that the smaller pieces take precedence over the larger, or that the larger subsume the smaller pieces it comprises. Instead, it is simply a recognition that information inheres in a large variety of things ${ }^{96}$ and results from myriad processes.

\section{B. Owning Information: A Framework for Inquiry}

While it seems clear that within legal and cultural understanding information is perceived as being subject to ownership, there remain questions about whether information can really be owned. These questions arise primarily because information is intangible, ${ }^{97}$ and thus the spread of information is difficult to stop. ${ }^{98}$

Difficulties with treating information as a thing to be owned have given rise to numerous doctrines intended to articulate a theory of information as a commodity or good that can be owned. One example is the distinction used in copyright law between an idea and a particular expression of that idea. ${ }^{99}$ The creator of an expression of an idea has rights in that particular expression of the idea but not in the idea itself. ${ }^{100}$ Though

mation' in any ordinary sense of either word."). This language, however, is not at odds with the understanding that information can be made up of other information. The Postal Service's argument in this case, as rejected by the court, was ostensibly the opposite: that once something can be identified on the whole as information, the constituent pieces of information that make up that whole are no longer cognizable for purposes of the Freedom of Information Act ("FOIA"). Id. While the language the court chose indicates that the whole-here, the contract-cannot be considered information, this is an indication only that it was still required under FOIA to investigate whether the constituent pieces of the contract were information, and could not simply look at the whole in this regard.

96. The "thingness" of information is also consistent with meme theory, as memes are thought to exist physically. See DAWKINS, supra note 88, at 192 ("[T]he meme for [a particular belief] is actually realized physically ... as a structure in the nervous systems of individual[s] the world over.").

97. This is true even though a particular expression of information recorded in a medium, such as an audio compact disc, might be held in one's hand.

98. Anyone who has been the object of gossip and rumors can attest to this fact.

99. See Feist Publ'ns v. Rural Tel. Serv. Co., 499 U.S. 340, 349-50 (1991) ("To this end, copyright assures authors the right to their original expression, but encourages others to build freely upon the ideas and information conveyed by a work. This principle, known as the idea/expression or fact/expression dichotomy, applies to all works of authorship.") (citations omitted); see also Alfred C. Yen, A First Amendment Perspective on the Idea/Expression Dichotomy and Copyright in a Work's "Total Concept and Feel", 39 EMORY L.J. 393 (1989).

100. See, e.g., Harper \& Row, Publishers, Inc. v. Nation Enters., 471 U.S. 539, $547-$ 48 (1985). The Court in Harper \& Row stated:

No author may copyright facts or ideas. The copyright is limited to those aspects of the work-termed 'expression'-that display the stamp of the author's originality. Copyright does not prevent subse- 
criticized by scholars, ${ }^{101}$ this so-called idea/expression dichotomy is well established in copyright doctrine and forms the basis of many judicial decisions regarding information ownership and use. ${ }^{102}$ It is one way in which the legal and economic system has attempted to grasp the nature of information in what on its face appears to be an attempt to provide incentives for its creation.

But there are many currently unresolved questions: whether ownership as an incentive to create is necessary, whether information can in fact be "owned," 103 and whether the idea of ownership of information is a good idea in general. ${ }^{104}$ As more information in a variety of forms passes easily over the Internet, ownership seems to be a more troubling concept. ${ }^{105}$

quent users from copying from a prior author's work those constituent elements that are not original-for example ... facts, or materials in the public domain-as long as such use does not unfairly appropriate the author's original contributions.

Id.

101. See, e.g., Amy B. Cohen, Copyright Law and the Myth of Objectivity: The IdeaExpression Dichotomy and the Inevitability of Artistic Value Judgments, 66 IND. L.J. 175, 231 (1990) ("[I]t is no longer necessary or valuable or even possible to dissect a work of art to uncover the universal truths or ideas which must remain freely available to all future authors.").

102. See Meade v. United States, 27 Fed. Cl. 367 (1992); Atari Games Corp. v. Nintendo of Am., Inc., 975 F.2d 832 (Fed. Cir. 1992); Frybarger v. Int'l Bus. Machs. Corp., 812 F.2d 525 (9th Cir. 1987).

103. Contrast this question of actual ownership with the concept of perceived ownership adopted below.

104. See, e.g., Yochai Benkler, Coase's Penguin, or, Linux and the Nature of the Firm, 112 YALE L.J. 369 (2002) (arguing for the recognition of a peer-based, rather than individual- or firm-based, mode of production that is facilitated by the existence of digital communications, rather than the traditional incentives allegedly provided by ownership and property rights in information) [hereinafter Benkler, Coase's Penguin].

105. One recent commentator has even argued that information has not truly been property in the past, and is only now becoming true property because of the technical ability to encrypt information and to preclude those who do not pay from decoding it; it is because of the ability to exclude others in some physical form that information can become property. Randal C. PICKER, From Edison to the BROAdCAST FlaG: MeChaNISMS OF CONSENT AND REFUSAL AND THE PROPERTIZATION OF COPYRIGHT (U. Chi. Law \& Econ., Olin Working Paper No. 159, 2002), available at http://papers.ssrn.com/sol3/ papers.cfm?abstract id=329340 (last visited Dec. 3, 2003). Portions of this argument have their difficulties-I have, for example, no efficient technical means to preclude someone from picking up my pencil from the desk, but I still consider it my property. I could put the pencil in a vault or a safe, but this could also be done with information. In both cases, once the vault is open, the information (and the pencil) are unprotected. Yet both can still be considered property. Technical encryption neither makes nor breaks the idea of information as property. Understanding, however, that technical encryption al- 
These questions aside, this Article proceeds along a more pragmatic route for evaluating ownership. The assumption is that statutory legal structures provide the basis for the perception that something is property. Property, under this conception, evolves from a set of rules or structures intended to provide members of society with a clear idea of rights and duties in relation to certain things defined by that society. To determine, then, whether information is property, and as such can be owned, we must examine whether and to what extent the rights given in information are analogous to those given in other, more established property settings. The rights to which we will look include the right to use, the right to exclude others from access and use, and the right to transfer (also known as the right to alienate). ${ }^{106}$ If we conclude that these rights can be found in relation to information, then information can be considered property, and it can be owned. ${ }^{107}$

It will be critical throughout this inquiry to keep in mind our definition of information as any thing that might be acted on based on its content, and to recall that information need only have the potential to convey meaning, and that one "piece" of information may itself contain distinct pieces. Ownership of one piece does not necessarily imply ownership of its individual and component pieces, and ownership of one component piece does not imply ownership of the whole. Rather, we must be explicit

lows greater protection for information as property, a point made by the article, is certainly important to understanding the nature of information as property today.

106. This view of property is not universal. There are a number of theorists who argue that exclusion is the lynchpin to a finding that something is property. See Merrill, supra note 4, at 736 (discussing views of property and categorizing them as "single variable essentialism, multiple variable essentialism, and nominalism"). Single variable essentialists argue that the existence of the right to exclude makes something property. Multiple variable essentialists argue that the right to exclude is a "necessary but not a sufficient condition" for finding property. Id. This means that without the right to exclude, a thing is not property, but something more than simply the right to exclude is needed for a thing to be property. Finally, nominalism views property as whatever the legal system decides to call property; it has no form or function outside of the definition provided for it by the legal system. Id. at 737 . While this last approach might seem similar to the one taken here (for example, states can create property by law, statute, and interpretation), this is too simplistic a view. Instead, Adam Mossoff's recent article advocating an integrated view of property, where all the rights noted above-acquisition, use, and disposition - are important to our conception of property more accurately reflects the view espoused here. Adam Mossoff, What is Property? Putting the Pieces Back Together, 45 ARIZ. L. REV. 371 (2003).

107. Adam Mossoff concludes, within the integrated theory of property, that information is property, and that intangibility creates no impediment to our understanding of information as property. Id. 
in articulating exactly which piece of information is owned when considering information as property. ${ }^{108}$

\section{Owned Information}

\section{Introduction}

There is a critical distinction among the views adopted by different disciplines concerning the creation and existence of property rights. Legal scholars generally refer to the statutory, judicial, and regulatory environment when asking whether property rights exist as to a particular thing. ${ }^{109}$ Economic theorists, however, generally insist that property rights exist where some person has the ability, not necessarily the right, to control the thing and to obtain or influence the income stream from it. ${ }^{110}$ Thus, someone who steals a car has no legal property rights in the car, but does have all or nearly all of the economic property rights in the car once it is in his possession. ${ }^{111}$ Legal rights, then, can influence economic rights, but they cannot be entirely determinative of them. Instead, economic property rights are bestowed by physical and cultural means in addition to legal means. ${ }^{112}$

The legal doctrines of copyright, trademark, trade secret, and patent are the structures that create legal property rights in information. Within these structures, information is viewed as something that is owned, and given additional power conferred by technology, such as the ability to encrypt data or content so as to prevent those who have not paid access fees from using it, economic property rights can be gained as well. While each of the four legal regimes of information ownership creates differing, and at times overlapping, rights with respect to the information covered, each provides at least some rights that can be characterized in terms of use, ex-

108. This is not to digress into the "bundle of rights" theory of intellectual property ownership. Rather, it indicates that as with all things, information has properties, and those properties themselves may consist of information that is owned or unowned in its own and separate right. As to the bundle of rights theory and the exclusionary theories of property ownership, see Mossoff, supra note 106. As to things being made of other things, see Sellers, supra note 72.

109. See, e.g., Andrew Beckerman-Rodau, Are Ideas Within the Traditional Definition of Property?: A Jurisprudential Analysis, 47 ARK. L. REV. 603 (1994) (concluding that common law idea protection, trade secret law, and patent law are all property based regimes predicated on the recognition of property rights in ideas).

110. See YorUM BARZEL, ECONOMIC ANALYSIS OF PROPERTY RIGHTS (2d ed. 1997).

111. The cliche "possession is nine-tenths of the law" actually more accurately reflects the economic view of property rights, and not the legal view. Of course, "possession is nine-tenths of the obtaining economic benefit" is not quite as catchy a phrase.

112. BARZEL, supra note 110 . 
clusion, and alienation. It is not necessary to delve deeply into the doctrine of each of these four areas to grasp the concept that together they provide a structure for information ownership. A brief review of the relevant concepts from property law, followed by a discussion of how each is handled by information ownership laws, will suffice to prove that information is indeed subject to ownership.

\section{Property and Rights in Brief}

In addition to identifying the rights that are present when we discuss property, it is also useful to clarify property by form of ownership. There are three generally recognized structural forms of property ownership: private, public, and common. ${ }^{113}$ In private and public ownership, an identifiable person or group of persons controls the property in question. Property that is held in common is conceived of as property to which every person has equal rights-it is still property, but it is not "owned" property. ${ }^{114}$ In addition, some common property may be further limited, in essence controlled by a group of people, none of whom can exclude others within their group from use, but who together as a group exclude "outsiders" from use. $^{115}$

As to purely common property, no one acquires the rights that inhere in property until it is claimed or converted from the public domain to private use. ${ }^{16}$ This does not mean that one cannot use it, but rather that one cannot exclude others from using it. ${ }^{117}$ In a limited commons, those who have control of the property can exclude "outsiders" from using it, but may not exclude others who have rights to it. ${ }^{118}$

In order to undertake the ultimate analysis required here, we must consider information ownership in light of our understanding of property. Thus, where property is defined by the existence of some combination of rights, the answer to the question of whether information can conceivably be viewed as property is to be found in considering the rights that information owners are granted under information ownership doctrines. The answer, as we shall see, is that information can be viewed as property.

113. See Carol Rose, The Several Futures of Property: Of Cyberspace and Folk Tales, Emission Trades and Ecosystems, 83 MINN. L. REV. 129, 129-44 (1998).

114. See id.

115. See id.

116. See id.

117. See id.

118. Still, a limited commons is not necessarily uncontrolled even as to those people who may not be excluded. Common property in Medieval England was often subject to restrictions and controls on its use, such as the number of sheep that could be grazed on it. See id. 


\section{Information Ownership}

Literature concerning information often bemoans the manner in which information has become propertized and commodified. ${ }^{119}$ Seldom if ever, however, does this literature question that information is viewed as subject to an ownership regime created by copyright, patent, trademark, or trade secret law. That is, we believe on the whole that information is property, even though we are not necessarily happy with that conclusion.

Returning to the basic predicates of property-possession and use, alienation, and exclusion - the doctrines of copyright, patent, trademark and trade secret provide these elements in relation to information. These laws together make up the property regime applicable to information, and within this regime, information is seen as being owned. For example, copyright law provides exclusive rights to the creator (or owner) of works, including the right to exploit and alienate those works. ${ }^{120}$ The exclusivity of the rights gives the copyright owner the legal authority necessary to exclude others. ${ }^{121}$ Patent law provides similar protections for inventions. ${ }^{122}$ Trademark and trade secret law add breadth to the ownership of information through the protection of marks in commerce and information that is protected by the owner from disclosure. ${ }^{123}$

Note additionally that the U.S. Supreme Court has held that the doctrinal schemes that provide at least certain rights for protection of information ownership-trademark ${ }^{124}$ and patent law, ${ }^{125}$ for example-are property rights, and may even be subject to the protections of the Takings

119. See, e.g., Niva Elkin-Koren, Cyberlaw and Social Change: A Democratic Approach to Copyright Law in Cyberspace, 14 CARDOZO ARTS \& ENT. L.J. 215 (1996).

120. See 17 U.S.C. $\$ 106$ (2000) (granting a copyright owner exclusive rights in copyrighted works, which include the right to reproduce, prepare derivatives, distribute, perform, and display).

121. The right of exclusivity is so strong it has been buttressed with additional rights in the form of the Digital Millennium Copyright Act's "anti-circumvention" provisions, designed to prevent frustration of exclusivity. See id. $\S 1201$.

122. See 35 U.S.C. $\S 271$ (a) (2000) ("Except as otherwise provided in this title, whoever without authority makes, uses, offers to sell, or sells any patented invention, within the United States or imports into the United States any patented invention during the term of the patent therefor, infringes the patent.") This language creates the right to use and distribute in the patent holder, and also gives the corollary right to exclude others from using or distributing it. See also id. $\S 261$ ("Subject to the provisions of this title, patents shall have the attributes of personal property.").

123. See 15 U.S.C. $\S 1114(2000)$.

124. See K-mart Corp. v. Cartier, Inc., 485 U.S. 176, 186 (1988).

125. See, e.g., James v. Campbell, 104 U.S. 356, 358 (1981). 
Clause of the Fifth Amendment. ${ }^{126}$ This adds further credence to the notion that information is viewed as property within legal and cultural circles.

\section{Conclusion}

Within the structures of copyright, patent, trademark and trade secret, there are rights provided in information that afford the same types of protections secured to real property owners. These rights are not necessarily unlimited, but nothing in property theory requires unlimited rights for property to be considered property. The rights systems themselves may overlap as to particular pieces of information, but this also is not fatal to our conception. A piece of land may be subject to both an easement and a lien, yet that piece of land can still be owned. Overlapping property rights schemes go more to the specificity with which we view information than to the actual ability to own information. Within the broad definition of information we have adopted here, information is clearly viewed as something that can be owned.

\section{Economics of Information}

Several aspects of information factor into an economic analysis of information as a commodity. Information is generally considered a public good $^{127}$ since many people who want to use a piece of information at one time theoretically can do so without other potential users being precluded from its use. One person using a piece of information does not prevent another person from using that same piece of information, either for the same or a different purpose, or at the same or a different time. This makes information non-rivalrous, meaning that it can be used without depletion. ${ }^{128}$ In addition, it is difficult to preclude people from using information. It can be distributed in a variety of ways because it is non-rivalrous, the "original" creator or distributor may not even know distribution is occurring. This makes information non-excludable: users who have not paid for it can be kept from using it only at very high costs. Absent legal protection, information produced by one person is easily used and distributed

126. The Fifth Amendment to the U.S. Constitution provides, in part, "nor shall private property be taken for public use without just compensation." U.S. CONST. amend. V. The Fifth Amendment was applied to intellectual property in James v. Campbell. 104 U.S. at 358 .

127. No one seriously disputes the public-good nature of information. See, e.g., Julie Cohen, Copyright and the Perfect Curve, 53 VAND. L. Rev. 1799, 1807 n.21 (2000). What is disputed is what to do about information being a public good.

128. Id. 
by others, without deprivation of use or provision of economic benefit to the creator. ${ }^{129}$

This understanding of information as an economic good allows us to see that information has inherent difficulties in any attempt to "own" it outside of the legal structure. While a builder may use force to defend against occupation of a house before it is paid for, once an informational good is out there, it is difficult to prohibit anyone's use of it without legal protection. Legal structures build in exclusivity for the purpose of creating a legal market where none would otherwise exist.

\section{E. The Nature of Information}

While the economic nature of information can be identified, not everything can be defined and described in terms of economics. It is therefore especially important to understand information's non-economic nature. As with the economic nature of information, the most critical elements of the non-economic nature of information come from its intangibility. This intangibility leads to information's description as a public good in economic terms. ${ }^{130}$ But it also leads to another important element in information's existence: slight changes in how information is expressed can lead to the meaning ${ }^{131}$ being passed along without distribution of the original piece of information. For example, one person can read a book and tell another person about it; the second person may not need to read the book in order to learn about and understand the idea behind the book. The book contains a particular expression of meaning. That meaning can be passed from person to person, even if the book itself or the precise expression contained within it is not transferred.

This ability of information to be distributed independent of its particular expression is critical to understanding how the semicommons theory applies to information as property. Not only does this separable quality underlie the public good aspects of information, namely non-excludability and non-rivalrousness, it also shows that something else is happening with information, something that requires us to think of information using a metaphor other than physical property.

129. Id.

130. See id.

131. Recall that above we adopted the definition of information as any thing that can be acted upon based on its content. See discussion supra Part IV.A. 
A further aspect of information is that it is essentially timeless. ${ }^{132}$ While the truth of certain information may be disproved over time, or become lost or distorted, the information itself can theoretically remain perfect throughout time. If someone was to write the phrase "the sun rose at 3:54 a.m. on Tuesday, March 4, 2003," it is easy to imagine this information being recalled exactly as it had been written originally, even 200 or more years later. While some tangible commodities may also be essentially timeless - diamonds, for example, do not necessarily deteriorate over time ${ }^{133}$-there is no tangible commodity that has the potential for exact continued existence to the extent that information does. ${ }^{134}$

This should not be read to imply that the value of the information does not change over time. Certainly it does, but it is nearly impossible to broadly define the way in which that value changes. Some information becomes more useful over time, other information less so. Some information that has had relatively little value may suddenly become very valuable. Information might be valuable only for a narrow purpose for a specific period of time. Applying another meteorological example, a report of the weather on a particular day might have relatively little value. However, the information could be extremely important in a case involving an automobile accident that occurred on that day. ${ }^{135}$ The timelessness of information is thus rather unique in terms of commodities.

An additional element of information that distinguishes it from more traditional, tangible commodities, involves the ability of particular pieces of information to exist in many different forms. The same piece of information might exist in writing, in digital form, in video, in a recorded audio track, or even in someone's mind. In contrast, tangible commodities might exist in different forms, but the exact commodity cannot. Consistent with

132. This argument is not an argument that the value of information is timeless, but simply that the "thing" we call information can theoretically exist without much difficulty in perpetuity.

133. Deterioration here is meant to follow the line that information is timeless as to itself, not as to value. Information goods can be depreciated in the economic sense of that term, and lose value over time, but the information itself stays the same. The same cannot generally be said for tangible goods, which require maintenance and additional expenditure at the very least to continue in existence, though some tangible items are more durable in this respect than others.

134. This does not guarantee that information will exist forever, but only that under the proper circumstances it could exist forever.

135. This discussion points out the distinction between depreciation or value, and deterioration of a good. In terms of the good, so long as it is remembered or recorded in some way, the information can be in existence forever, and can be "working" during that time. It does not physically deteriorate-again, for the very reason that it is different from most other goods, it is intangible-and so can exist in perpetuity. 
the laws of physics, matter can exist in only one place at one time. Information's intangibility allows it to escape this physical restraint.

The multiplicity of forms of identical information leads to another distinction between the tangible and the intangible. Information is subject to distortion in ways that other commodities are not. For example, if someone remembers reading the statement that the sun rose at a certain time on a certain day, but recalls the details incorrectly, the original piece of information has changed or become distorted. The false belief as to what time the sun rose is still information, but it is no longer identical to the original piece of information. As such, information can lead to and create new information without replacing or destroying the original.

One final and potentially significant aspect of information as a commodity is that there is no conceivable way in which all information can be owned. The accuracy of this statement becomes clear once we consider the breadth of what is covered by our definition of information. Recall that, according to our definition, the meaning potentially conveyed need not be true or accurate; indeed, it can even be false. False information is still information, even if it is not useful in the end.

Some examples of what qualifies as information are helpful to illustrate this final point. A tree can convey information; an observer might see that the tree's leaves are falling and conclude that it is autumn. Broken glass lying next to a car with a broken window on a city street can convey the information that the car has been broken into. A flag stretched taut from a flag pole can convey the information that it is a windy day. Certainly, more staid and conventional things can convey information: books, movies, sounds, images. But even given these more formal kinds of information, it is difficult even to conceive of a world where all information could be owned, where one would be required to reimburse another when she sees the waves rolling onto the beach or hears the call of the eagle on the wind (or perhaps just as importantly, when she tells-that is, distributes-that information to others). The waves and the eagle's cry can both be acted upon due to their content, and thus meet our definition of information. But the idea that someone could possibly own that information is beyond comprehension. The existence of such a wide variety of information, in a world where essentially everything can convey information, makes it clear that all information cannot be owned, regardless of the strength of information rights enforcing technology or the manner in which the law is written regarding it. The implications of this conclusion are set aside for now. 


\section{F. Final Thoughts}

We generally perceive information as being subject to ownership. Our media, judicial, and legislative discourse echoes this perception. It is clear, however, that when we pause to consider the meaning of the term information, and in turn consider the application of that meaning within present legal doctrine, not all information can be owned. However, for the purposes of the remainder of this Article, we will accept as true the perception that information can be owned. We do so only to allow us to engage in a discussion about the type of ownership regime that would exist if that perception were ultimately proven. It is to that task that we now turn.

\section{INFORMATION OWNERSHIP AS A SEMICOMMONS}

\section{A. Semicommons Theory}

In his article Semicommon Property Rights and Scattering in the Open Fields, Henry Smith identified and described the theory of semicommon property ownership. ${ }^{136}$ Initially, Smith adopted a simple property model to establish the existence of the semicommons, explaining, "On this view, private property rights will emerge when they are cost effective, and efforts at definition and enforcement of property rights will proceed until marginal benefit equals marginal cost." ${ }^{137}$ While acknowledging that this pattern can and does become more complex where appropriate, ${ }^{138}$ Smith focused on the costs of enforcing property rights to help avoid the quagmire of assumptions based upon zero transaction costs. Smith's article described the conditions under which semicommon property ownership becomes efficient.

In order for semicommon property ownership to be efficient when contrasted with purely private, purely common, or hybrid property schemes, this property regime must involve a dynamic relationship between the private and the common uses, with significant impacts of one type of use on the other. Once the dynamic relationship is established, the benefits of operating on multiple scales must outweigh the costs imposed on the ownership scheme by strategic behavior and its prevention. Thus, the nature of the strategic behavior must be considered, including either

136. Smith, supra note 7.

137. Id. at 133 .

138. Id. (" $[\mathrm{T}]$ ransitions to and from property regimes require contracting among participants. The institutional structure in which contracting takes place is also a key to the formation, persistence, and eventual destruction of a semicommons property regime."). 
how the benefits of the scheme outweigh the costs of the behavior or how strategic behavior is controlled or prevented.

In applying the semicommons notion to the open fields, Smith identified the dynamic relationship between private and common uses as the contrast between the economies of scale available for the grazing of animals and the private incentives required to encourage grain growing, ${ }^{139}$ which at the time enjoyed no economies of scale. ${ }^{140}$

The difficulty of the semicommons notion now becomes apparent. In any situation like the one described, individual property owners will attempt to overuse the commons to the extent that they can do so without suffering the costs themselves, presenting a classic tragedy of the commons scenario. ${ }^{141}$ In addition, they will attempt to both minimize the negative effects of common use on their own property and maximize the negative effects of their own private uses on the commons. ${ }^{142}$

According to Smith, there are four potential cases of strategic distribution of harms in the semicommons: 1) commons use imposes costs on commonly owned attributes such that each actor bears a proportional amount of the costs of use; 2) commons use imposes costs on privately owned attributes, either with a) all costs being imposed on the actor's own property such that the actor bears all of the cost for the use, or b) costs are imposed on other people's privately owned attributes, such that the actor bears none of the costs of the use; 3 ) private use imposes costs on private

139. Id. at 132 .

140. Smith did note that applications beyond the open fields should be considered in the future. Specifically, he noted that its application to intellectual property might be appropriate. See id. at 165-67 \& n.124. There are differences between Smith's original, albeit brief, notation and the proposal later outlined in this Article. In Smith's example, technology developers choose to make their technology into a semicommons, as did the farmers in the open fields (which might be termed a "created semicommons"). Id. The argument as to the regime of information ownership is that, at least in part, it would be difficult for it to be anything other than a semicommons (which might be termed a "natural semicommons") so long as private rights in information are provided for in law. If private rights of ownership in information were terminated, a pure commons would return; whether this would be sustainable or not is not the point. Rather, the question is instead how we would describe the state of affairs that would exist in that case. It is difficult to imagine a situation in which all information is owned, or even that all use of any one piece of information can be forbidden. The conclusion is that private use and common use must coexist in information, and that because of this, information ownership is a natural semicommons.

141. Id.

142. This does not necessarily imply that a deceptive or "bad actor" attitude is being reflected. Rather, it is understandable to attempt to minimize costs to oneself, even if that minimization involves shifting those costs to the commons and its other users. 
property, either with a) costs imposed on the actor's own property such that the actor bears all of the cost for the use, or b) costs are imposed on other people's privately owned attributes, such that the actor bears none of the cost of the use; or, 4) private use imposes costs on the commonly used attributes of the property. ${ }^{143}$

The types of strategic behavior in the open fields revolved primarily around the private user's attempts at maximizing the value of the commons use while minimizing private costs. In this instance, the animals were the common property. Benefit could be derived from the common property if the shepherd could be persuaded to station the flock on one's private property overnight. This provided fertilization for the private owner's crops. In contrast, the daytime activities of the animals imposed costs on owners of private property, as the animals ruined crops by grazing on and walking over them. Thus, when a private owner of property could convince a shepherd to station the flock on his property overnight, but graze the flock elsewhere in the daytime, that private owner would benefit. The benefit of the commons use was the fertilization that occurred when the animals were kept in an enclosed (and ostensibly private) area overnight. ${ }^{144}$ A private user, for example, an individual land owner, who could encourage, pay, or otherwise coerce the shepherd in charge of the grazing to station the flock on his property overnight would gain additional fertilization. In contrast, the daytime activities of the flock, walking and grazing, could impose costs on a private user through the acts of walking and grazing. Where a shepherd could be convinced to graze the flock elsewhere, a private owner would benefit. ${ }^{145}$

The strategies set up to avoid the private strategic behavior were primarily based on altering the borders of the private use areas so as to make the costs of engaging in the strategic behaviors prohibitive. "Scattering" is the term applied to the private use scheme, where a private owner's lands were scattered throughout the entire range of the grazing land. ${ }^{146}$ Scattering increased the cost of engaging in strategic behavior: it made it difficult, if not impossible, for the shepherd to identify whose land the flock

143. Id. at 139. Omitted from Smith's conception of strategic behavior under possibilities two and three are the two possibilities in which costs are imposed either by common use (under use type two) or private use (use type three) on all private users. See id. In such a case, though unable to strategically avoid all injury to the privately owned attribute, the actor will attempt to maximize costs imposed on the privately owned attributes of others and minimize the costs as to her own privately owned attributes. See id.

144. Id. at 149-50.

145. Id. at 150 .

146. Id. at 146 . 
was either grazing upon in the day or enclosed in for the night. Because the lands were not clearly marked, it would have entailed the expenditure of significant amounts of effort, for the shepherd and a private user to agree to the strategic grazing or enclosure of the flock. Through scattering, strategic behavior was minimized, but the dynamic benefits that flowed from using the land for both private and common uses, continued to be valuable. ${ }^{147}$

The costs for the property system of avoiding the strategic behaviors is the crucial issue in terms of recognizing an efficient semicommon property scheme. Where the benefits that flow from the dynamic relationship between the public and common outweigh the costs of avoiding the strategic behavior, the semicommons will continue to exist. Where another form of ownership becomes more efficient through either a new way of allocating rights, such as through contract, or where there are changes in the nature of the strategic behaviors themselves, semicommon ownership may no longer be efficient. ${ }^{148}$ In the open fields example used by Smith, the ability of private users to efficiently allocate ownership and use rights through contracts led to enclosure. ${ }^{149}$

In summary, a semicommon property regime will come into existence where the benefits resulting from the dynamic interaction of private and common uses outweighs the costs imposed by the need to prevent strategic behavior on the part of the private users. Other forms of property ownership are likely to emerge where changes in the nature of the strategic behavior raise enforcement costs or where the methods of allocating rights lead to lower costs for these other forms of property ownership. We now address how this scheme plays out in the information realm.

\section{B. The Information Semicommons}

Moving from the semicommons as outlined by Smith to the information semicommons is a logical step. Once we accept that information ownership law creates a property regime in information, the application of the semicommons theory to that property regime is readily achieved. That achievement, however, entails a more detailed exposition of the dynamic nature of the private and common uses of information than was required for Smith's account of the semicommons in the open fields.

Smith was concerned, in significant part, with showing that scattering in the open fields was in fact an economically efficient response to the

147. Id.

148. Id. at 160 .

149. Whether a similar fate is in store for the information semicommons is a question left aside for the moment. 
need to control strategic behavior. ${ }^{150} \mathrm{On}$ its face, scattering appeared to be inefficient, as it required farmers to farm in varied locations. But, as Smith pointed out, this misses the overall economic picture. ${ }^{151}$ There were no economies of scale for farming during this time period, but there were economies of scale to herding. In order to take advantage of scale in herding, while maintaining the incentives for private individuals to farm, strategic behavior needed to be prevented. In addition, the costs of avoiding the strategic behavior needed to be lower than the benefit that resulted from this form of semicommons cooperation. Scattering of private plots, and thus private uses, was part of the overall scheme used to prevent strategic behavior, and viewed in this light, it was a rational and economically efficient method of ownership. ${ }^{152}$

As noted above, these burdens, benefits, and strategic behaviors can be readily described and discussed. Smith's attention to the economic justification for scattering, rather than on developing categories for strategic behaviors is thus easy to understand. Making the case for the existence of the semicommons, as opposed to explaining the particulars of its functioning, was the comparatively easy part. ${ }^{53}$

The information semicommons is more complicated. For this conception of information as property to be plausible, this Article must establish that the relationship between common and private uses is in fact dynamic, with interdependencies between the uses analogous to those found in the open field semicommons. If the benefits flowing from the combined private and common uses do not flow to both types of uses, a semicommons approach is inappropriate.

\section{Private and Common: Information Use Dynamics}

Private and common information uses interact. This interaction is not just the "push and pull" variety: it is not simply a conflict of uses where one is always antagonistic with the other, where each vies for the right to use information in a particular way. Rather, the interaction is dynamic: private use affects common use and common use affects private use, and both types of uses are better off for the existence of the other. This is not a claim that every single type of use, even that which cannot be considered

150. Smith, supra note 7 , at 134 .

151. Id.

152. Id.

153. This is not to say that making the case for the existence of the semicommons was easy per se, but rather that describing the implications in terms of dynamic relationships between private and common use for the open fields required comparatively greater effort. 
strategic behavior, is beneficial on a micro level to other uses. Not all common use is beneficial to every private use, and not all private use is beneficial to every common use. Rather, the claims made here about the value, benefit, and dynamic interaction of information uses are made at the macro level, and must be addressed in that framework.

Even at the macro level, identifying the precise ways in which the interactions occur, ways that show the dynamic nature of the interdependence of the private and common uses, is not a simple task. ${ }^{154}$ For purposes of this Article we will refer to two levels of interaction: content level and distribution level. Content level interactions are those that are involved in acting on or because of the substance of the information or its meaning. An example of such an interaction is the discussion that ensues when a new scientific theory is presented at an academic conference. The presentation of the theory, along with the reasoning that supports it, will undoubtedly lead to a discussion of the principle by the participants and, perhaps, an improvement upon the idea. This is content level interaction: the information is presented, other information and processes act on it, and the information is in some way changed.

A change resulting from interaction occurring at the content level can be an improvement in the information from a normative perspective, that is to say that the information might be better than it was before. On the other hand, the importance of the information may be diminished, resulting in the rejection of the information based on its content. Interaction at the content level is a critical aspect of the information dynamic of the type being described here in the information semicommons.

Information interaction also occurs at the distribution level. Distribution level interactions are those that occur when an interaction has an effect - market-based or otherwise - on the distribution of information.

Sometimes content level and distribution level interactions appear to overlap or conflate, but in fact the interactions can generally be teased out

154. It might be argued that authors or creators are not the proper focus of creative activities. The rejection of "authorship" has been in vogue in recent years, with a steady stream of scholarship that rejects the notion that works are created by individuals laboring alone and away from the rest of the culture. Such theories hold that the author is thus not the correct focus of information protection, and that information protection has been and is being overextended in terms of protections provided to authors. Whether one accepts or rejects these arguments is not at issue here, as this piece is concerned primarily with arguing that information rights regimes as they currently exist create a semicommons in information. It is clear that information rights are based on the acceptance of the author/creator paradigm, and as such attacks on it would, if successful, alter the nature of the information ownership regime in ways that are beyond the scope of this Article. See infra note 155 and accompanying text. 
separately. For example, if a book review is published about a new novel, the book review will likely have dynamic effects on the original novel at both levels of interaction. Assume the book review is positive, encouraging readers to take the time to read the novel, while also discussing the novel's theme. At the content level, the review's treatment of the novel's theme might cause another novelist, or a critic or discussant, to take up or consider alternative points that otherwise might not have been raised in relation to that theme. That is interaction at the content level.

At the distribution level, the positive review will likely lead to greater sales than would have occurred without the review. The strength of the distribution level interaction effect will vary depending on the place in which it occurs. For example, a book review in a small circulation newspaper will likely give less of a boost to sales than inclusion on the reading list for the now defunct "Oprah's Book Club." Note that the effect at this level does not extend to the content: we are unconcerned with the substance of the book when considering the distribution level interaction. Instead, we see the common use interacting with the private use-in this example, the discussion of the book and its theme interacting with the initial creation of the novel.

The dynamic relationship between the private and common uses of information is thus encapsulated within these two levels. Within the content level, information interaction leads to the evolution of existing information and to our understanding of that which we do or do not "know." At the distribution level, the effects are primarily, although not exclusively, economic; the discussion or passing on of information has some effect on the market for the original and subsequent uses. Both levels may be involved in any particular interaction or use, but the effects of each are distinct. Even where both levels are present it is useful to tease out these distinct effects.

\section{Information "Creation" and Information Dynamics}

One of the easiest ways to see how private and common uses of information interact dynamically is to look at the information creation process. While the conception of a solitary author creating meaning entirely from whole cloth is well established in western culture, there are a variety of scholars who argue that this notion is a false one that is not born out by critical inquiry. ${ }^{155}$ Instead, the people who modern society considers authors create based on the whole of their experience, which includes previ-

155. See Mark Rose, Authors and OWNERs: The InVEntion of Copyright (1993); see also JAMES BOYLE, SHAMANS, SOFTWARE AND SPLEENS: LAW AND THE CONSTRUCTION OF THE INFORMATION SOCIETY (1996). 
ously created works and personal experience, understanding, learning, and knowledge. 156 "We stand on the shoulders of giants," is one metaphor used to describe creative efforts. ${ }^{157}$ We cannot discount entirely everything that has come before. Even when things seem entirely new, they borrow, beg, or steal from things which came before. This line of reasoning accentuates the idea that information interacts with information. Even if information is owned, it is likely to be recast and included (many times legally) in subsequent information creation.

Thus, for those who argue that information creation does not occur anew, it is easy to acknowledge that both private and common uses of information interact dynamically. In this conception of creation, existing information forms the basis of new information and understanding. That what is perceived as the "new" information, or at least, new expression of information, is privately owned does not alter this picture. New creation cannot be separated from old, and the dynamic interaction of the alleged private use with the common is apparent from the face of the positive claims about information creation.

This view of information creation is, within the framework of interaction laid out above, a primarily content level interaction. It is one in which existing information leads to and is enlivened by new information. It shows that private use, while limited within this conception of authorless creation, interacts with common use. New ideas spring from old ones, reusing or reframing concepts. Without the existing ideas, new ideas would not spring from the well of the commons, and would not then contribute again to it. Common use adds value to the private use, and private use adds value back to the common use.

As we have seen, however, this conception of authorship is not currently implemented in the structures of information ownership that are currently relied upon. ${ }^{158}$ Instead, the current system appears to accept at face value the idea of authorship and the concomitant need to provide economic incentives for information creation. ${ }^{159}$ Within the more accepted

156. See BOYLE, supra note 155; ROSE, supra note 155.

157. See Michael D. Birnhack, The Idea of Progress in Copyright Law, 1 BuFF. INTELL. PROP. L.J. 3, 42-45 (2001) (analyzing the standing on the shoulders of giants metaphor).

158. But see L. Ray Patterson, Copyright Overextended: A Preliminary Inquiry into the Need for a Federal Statute of Unfair Competition, 17 DAYTON L. REV. 385, 386 (1992) (arguing that the conception of authorship to works of "low authorship" was inappropriate).

159. Recall that claims such as these are made here in a positive, not normative, fashion. This Article should not be read to argue either that a property regime in information is necessary to provide sufficient incentives for the creation and distribution of informa- 
notions of information creation, then, the question of whether private and common information uses interact dynamically remains.

Even if we accept that the basis of current systems of information ownership rely on a conception of authorship as one in which the creator has rights because he created some information good that is new or unique, we can still identify a number of dynamic interactions between private and common uses of information at both the content and the distribution levels. Initially, let us consider the example of a biography of an actual person in printed book format that is written by an author and distributed by a publishing house. When the book is released, information about it must also be released. Without information describing the book, or at least its availability, no one will know it is available and thus no one will buy it. The information made public about and surrounding the book's release provides us with information about dynamic interactions between private and common uses of information.

The book is a private use of information, protected by the law of copyright. In this case, it is built upon information that was available to the' author about a certain person, the times in which she lived, and the facts surrounding her life. It may also contain conclusions about the events and facts in which the biography's subject was involved, and these conclusions may appear in explicit form for the first time in this biography. To that extent, the biography is a mix of information, some novel, some not.

When the book is released, it is in the best interest of the author and distributor to make the general public aware of it. In this regard, advertisements might be placed in newspapers, magazines, or other publications. As these uses are all by and for the author and distributor, they are still private uses, and are under the control and within the legal structures established for such uses. But advertisements can only have so much effect on the public's buying preferences. Advertisements are paid for by the author and distributor, and the public knows this. Thus, claims by the author about the book's relevance, importance, style, or value are perceived as biased. The private use of information in this way is not likely to meet all of the author's and distributor's goals, which are to distribute the book as widely as possible for profit.

The author and publisher thus might welcome additional publicity in the form of book reviews. These reviews, written by independent third parties, will almost always include quotations, sometimes rather lengthy ones, in which the words of the author are used verbatim to emphasize a

tion, nor that the author model of information creation embodied in the current regime is accurate in terms of the manner in which information is in fact created. 
point being made in the review. In a world of purely private rights in information, the book reviewer would need to obtain permission from the author, and perhaps even pay a fee, to use her words in his review. However, under copyright law, no permission is necessary where the use being made is fair. ${ }^{160}$ Criticism in a book review, and inclusion of some of the author's words, is likely to be viewed as fair use in this context. ${ }^{161}$ This then becomes a common use of the information that is otherwise subject to the private ownership of the author.

This common use of the text in the review allows a reader of the review to see the actual writing of the author, to examine the style and method used in determining whether it is something she would enjoy reading. A reader's likelihood of buying the book will depend on whether or not she likes what she reads. This is a distribution effect of the interaction of the private and common uses. Of course, strategic behavior is possible on the part of the private use author. For example, the author might try to forbid uses of her text in negative reviews ${ }^{162}$ But putting such strategic behavior aside for now (it will be addressed in greater detail later), the dynamic interaction at the distribution level between the common use and the private use is clear.

At the content level, the dynamics of the interaction can be even more pronounced, even if we only consider the effects of the uses on each other and not on outside markets or on considerations such as free speech. Within these more limited constraints, let us take a new example of an information good: this Article. It explicitly attempts to build upon the ideas that are contained within, among others, the writings of Henry Smith. His semicommons article forms the basis for both the conception of information as property identified here and its application. In this manner, his article has formed the basis for a new work, a new work that arises out of his private use.

This new information work, however, also has the potential to have an effect on the work from which it draws. If the ideas within this article are

160. 17 U.S.C. $\S 107$ (2000) ("Notwithstanding the provisions of sections 106 and $106 \mathrm{~A}$, the fair use of a copyrighted work ... for purposes such as criticism, comment, news reporting, teaching ... scholarship, or research, is not an infringement of copyright.").

161. See id.

162. Franceso Parisi and Ben Depoorter detail another potential private ownership outcome that negatively affects the information semicommons, namely, the fracturing of ownership interests. Ben Depoorter \& Francesco Parisi, Fair Use and Copyright Protection: A Price Theory Explanation, 21 INT'L REV. LAW \& ECON. 453 (2002). This "tragedy of the anticommons" poses dangers that differ from those that come from viewing information as a commodity in search of perfect privatization. See id. 
accepted and adopted, or even discussed beyond the publication of the article itself, the original article has the potential to become more valuable in relation to the purpose for which it was originally written. It may be cited more frequently, and interest in it may also increase. This would represent both a content level and distribution level interaction. It is dynamic interaction at the level of information development, with significant potential for distribution effects. Readers who agree or disagree with the current article may well return to the work upon which it draws heavily, yielding an increase in the distribution of that work. This example shows that the dynamic effect need not be limited to one level, but that the effects can be evaluated in each case so as to more fully understand the nature of the dynamic interaction.

Finally, moving beyond the artificial limitation we placed on content level interactions, it is clear within the scheme we have described ${ }^{163}$ that private and common uses interact to the benefit of the development of knowledge and ideas of society as a whole. That is, when an author creates a new work, that work has the potential to enter the public debate. Where it does, parts or portions of the work may be used by common users in evaluating, discussing, criticizing, or advancing the ideas of the work. Some of these parts or portions may be subject to the protection of copyright, and their use may or may not be authorized within that scheme.

A new example illustrates the point. Assume that Copernicus has published his great work De Revolutionibus, in which he asserts that the world is round and orbits the sun. ${ }^{164}$ His work enters the public consciousness and becomes the subject of discussion. In terms of the search for knowledge, his work will be read, quoted, discussed, and critiqued. The common uses, such as discussion and critique, add to the contribution that the "original" work has made to the human store of knowledge. As such, if we were to provide information owners with the authority to exclude all common uses, the original work could only be advanced upon permission of the author, and would be limited by that author's own vision and understanding. ${ }^{165}$

163. Recall that the scheme as described accepts arguendo that the information property scheme's basis of creating economic incentives for information creation is valid. This is not an acceptance of that core ideal, but rather an acknowledgment that it has been implemented within the current legal structure that leads to property rights in information.

164. Nicholas Copernicus, De Revolutionibus (1520-1541), available at http://bj.uj. edu.pl/bjmanus/revol/titlepg_e.html.

165. The dangers of such an approach should be apparent, but an example will help to illustrate the point: Albert Einstein, famed for his pathbreaking and novel theories of 
Taken together, these examples make the case that private and common uses of information interact dynamically. When common uses are restricted, something is lost, not only to common use, but also to private use, something that is otherwise unrecoverable. In addition, loss of private use rights would yield an overall loss to both common and new private uses, assuming arguendo that private economic incentives are themselves necessary to spur information creation. This dynamic interaction of uses shows that information ownership in the current regime is not purely a private property regime, nor is it purely a commons. It is a semicommons.

\section{Strategic Behavior in the Information Semicommons}

a) Identifying Strategic Behavior in the Information Semicommons

As was true of the dynamic relationship between the private and common uses, the nature of possible strategic behavior in the open fields was readily identifiable and largely limited in its scope. ${ }^{166} \mathrm{~A}$ private user would be expected to bribe the shepherd to graze the flock on other private users' plots during the day and to pen up the flock on his property at night so as to avoid the detrimental effects of grazing while capturing the benefit of fertilization. ${ }^{167}$ Strategic behavior involves capturing as many of the benefits of the dynamic relationship as possible, while avoiding as many of the costs as possible.

There are many possibilities for strategic behavior in the information realm. One example is the unauthorized copying and distribution of information goods. Licenses and contracts are particularly relevant in this context. Because the owner of intellectual property has the explicit right to license or authorize its use by others (and thereby to exclude users as well), ${ }^{168}$ creators of digital goods may restrict the end user's right to make duplicates of the goods they have purchased. ${ }^{169}$ For our purposes, strategic

relativity and special relativity, is said to have rejected the idea of chaos playing a role in the laws of physics. If Einstein had been able to stop those who also believed in the role of chaos in physics from applying his theories, the progress of science would have been held back many years.

166. Smith, supra note 7, at 144.

167. Id.

168. 17 U.S.C. $\S 106$ (2000) ("[T]he owner of copyright under this title has the exclusive rights to do and to authorize any of the following.") (emphasis added).

169. Owners of information goods tend to use language that indicates the consumer has not bought the good itself, but rather has purchased only the right to use the good in accordance with the license. While licenses are often not available to purchasers prior to purchase, and thus questions of bargaining, consent, and related contract theory questions are certain to arise, judicial decisions seem on a trend to recognize such licenses and their 
behavior may either take the form of imposing restrictive licensing terms, especially where imposed by a monopolist, or it may entail a violation of those terms. Keep in mind that a violation of the terms of the license should not automatically be considered strategic behavior, just as imposing terms, in general, should not be considered strategic behavior on the part of the producer. It is when the actor seeks to impose costs or distribute costs across other common or private users, as outlined in Smith's theory, that strategic behavior should be of concern within the semicommons model.

Information counterfeiting is an example of a strategic behavior that either imposes a cost on or is distributed across other common or private users. Such counterfeiting is a multi-million dollar affair in the United States and the world today. ${ }^{170}$ It includes unauthorized copying and distribution of computer software, music and video compact discs, digital video disks, video cassette recordings, and other musical, visual, electronic print, and multimedia goods. Counterfeiting involves attempting to pass off an unauthorized product as the legitimate, authorized original good as produced by the owner. The copyright industry has dubbed this activity "piracy," and it includes any "unauthorized" copying of protected works. ${ }^{171}$ Counterfeiting is primarily a distribution level interaction: the content of the work is not being advanced, considered, or even evaluated. It is simply being distributed. Making a copy of a digital work is not inherently illegal, nor does such behavior by its very nature reflect a strategic choice on the part of the copyist. Problems arise only when the creation of the copy violates the rights protected by the information property scheme. Thus, it is not the falsity of the copies with which we are concerned, but rather, the

restrictions, and as such, the use of such language may be an accurate description of the transaction that occurs between the buyer and seller of information goods. See ProCD, Inc. v. Zeidenberg, 86 F.3d 1447 (7th Cir. 1996) (holding shrinkwrap license valid even though user did not have access to the license until after the purchase of the software package).

170. See, e.g., Motion Picture Association of America ("MPAA") Anti-piracy Web Site, at http://www.mpaa.org/anti-piracy/index.htm (last visited Nov. 4, 2003). The MPAA states that

The [MPAA] and its international counterpart, the Motion Picture Association (MPA), estimate that the U.S. motion picture industry loses in excess of $\$ 3$ billion annually in potential worldwide revenue due to piracy. Due to the difficulty in calculating Internet piracy losses, these figures are NOT currently included in the overall loss estimates. However, it is safe to assume Internet losses cause untold additional damages to the industry.

Id.

171. Id. 
distribution of the work in a commercial manner and in violation of the license provided by the manufacturer of the information good.

In addition to considering mass copying and distribution of "fakes," there are other strategic behaviors that involve copying and distribution. These differ from those mentioned above, and are not considered counterfeiting. Part of the distinction lies in the fact that their existence is not an attempt to profit monetarily from the original, but rather is intended to engage in a system of copying and distribution outside of the terms of the license for other purposes. Such other purposes might include the belief that the owner of the information good is too powerful, or that information should be "free" and unowned.

This non-commercial or non-competitive copying and distribution, generally considered a violation of the rights of the owners absent some valid claim of fair use (in the copyright arena), exists at various quantitative levels. Some non-commercial distribution occurs through organized peer-to-peer networks discussed throughout this paper, such as Kazaa or the now defunct Napster. These systems allow users to connect directly to each other's computers, and while they often facilitate the transfer of files through such services as generating lists of currently available files, ${ }^{172}$ in general they were designed to facilitate the sharing of any files, and are not specifically directed to the sharing of copyrighted works. Not all large scale sharing of digital goods takes place through peer-to-peer networks, however. Webpages facilitating the exchange of files, often more directly aimed at exchanging goods that are known to be covered by copyright, also exist, ${ }^{173}$ as do other methods for large scale sharing, such e-mail lists or special FTP servers.

In addition to the mass sharing of files, which appears to be a significant development in strategic behavior in relation to digital information goods, individuals often share information goods on a smaller scale, from the showing of videos in dormitory common rooms ${ }^{174}$ to the copying of video tapes or DVDs for friends to the "sharing" of software applications by providing installation disks to friends in situations where the original

172. For a file to be currently available, at least one user with the file on her computer must be signed on to the service in question at the time the file is sought.

173. These file sharing communities often utilize Internet storage that is not designed for the purpose of exchanging files, and depending upon the size of the community, can cause problems with websites that provide such services, such as overloading them and preventing them-at least for a time-from providing services.

174. This is technically a public display of the video, and is outside the license of most videos, whether owned or rented. 
installation is still in place. Such behavior implicates notions of strategic behavior.

Examples of non-strategic copying might be the making of back-up copies of software or musical works to allow a user to make use of the information which he or she has purchased if something were to happen to the original. In addition, altering the format of music files-for example, converting CD audio files into the smaller and more efficient MP3 format, and storing the files on one's computer or on one's MP3 player-may also be outside the definition of strategic behavior. ${ }^{175}$ The idea that the creator of the information good which one has purchased can dictate not only the number of copies that one may make of the work, but also how the person can listen to it on various media seems to be stretching the concept of ownership. ${ }^{176}$

As with counterfeiting or faking, small scale copying and distributing is primarily distribution level interaction. These activities are not generally concerned with discussing or advancing understanding on a content level, but are instead are only concerned with providing additional copies. This does not have to be the case, as the creation of playlists of songs, for example, is a creative exercise, and reflects a content level interaction with the information used-in this case, the songs that make up the list. The distribution may also lead to content level interactions by people who otherwise would not have been exposed to the information in question.

The common use strategic behaviors identified so far have been primarily distribution level interactions; content level strategic behavior is more difficult to categorize. There are some cases in which a person takes a portion of an information good, such as an article or a book, and claims it as his or her own. ${ }^{177}$ While at first this might seem to resemble counterfeiting, it does so only at the most basic level. However, in cases of plagia-

175. See, e.g., Recording Indus. Ass'n of Am. v. Diamond Multimedia Sys., Inc., 180 F.3d 1072 (9th Cir. 1999) (bringing against manufacturer of MP3 player for facilitating copyright infringement).

176. Information owners, of course, will not necessarily agree with this analysis. If the tracks of an audio CD are converted into MP3 format on a computer, they remain on the $\mathrm{CD}$ as well. If someone is listening to the $\mathrm{CD}$ at the same time that the MP3 tracks are being played elsewhere, information owners would argue copyright law, both in spirit and in explicit terms, is being violated. See Diamond Multimedia Systems, Inc., 180 F.3d 1072 (9th Cir. 1999), in which the Ninth Circuit rejected these claims, bringing MP3 player use, even the "ripping" of music tracks, within the protection of the Audio Home Recording Act, 17 U.S.C. $\S 1001$ (2000). 180 F.3d at 1081.

177. This is often referred to as plagiarism, especially in the academic world. See Lisa Lerman, Misattribution in Legal Scholarship: Plagiarism, Ghostwriting, and Authorship, 42 S. TEX. L. REV. 467 (2001). 
rism, the plagiarist does not acknowledge the existence of the owner, and instead personally claims the rights to the work, whereas the counterfeiter acknowledges someone else's ownership of the good, but pretends that the good is authorized or produced by that owner. The plagiarist's act is no less strategic behavior, however, because of this difference. In both cases, the common user attempts to claim the work, including the rights to the original, as his own property. This situation presents us with strategic behavior at a mixed distribution and content level, as the plagiarist is likely to change at least some parts of the stolen text. In so doing, the plagiarist introduces content level effects (recall that content level effects need not be positive).

Strategic behavior, however, does not just exist on the part of the common users in terms of copying and distributing information goods outside of the terms of a license. Private owners of information can act strategically as well. These strategic behaviors arise out of the method by which information owners grant access to their information. Owners will be selective in deciding who may receive rights and will likely base their decision on the proposed use to be made of the information. Owners may also base this decision on the economic effects of the manner in which they license the work. In addition, if the information protection scheme is designed to provide incentives for creation and innovation, then actions that keep information from use would seem to run counter to that notion, and the use of intellectual property law for these purposes is likely to fall within our definition of strategic behavior.

The types of behavior that would be strategic in this latter respect include requiring the purchase of additional information or non-information goods so as to be granted legal access to the desired information. ${ }^{178}$ Such agreements attempt to take advantage of the desirability of particular information to advance the economic interests of the owner. As such, the interaction is primarily at the distribution level, for it is concerned not with the content of the information, but with tying other, less desirable products with it. Tying is one type of distribution level strategic behavior in which private owners of information engage. ${ }^{179}$

178. This is an anti-competitive behavior known as tying. See David Gilo, Retail Competition Percolating Through to Suppliers and the Use of Vertical Integration, Tying, and Vertical Restraints to Stop It, 20 YALE J. ON REG. 25 (2003).

179. Not all tying should be considered negatively in terms of strategic behavior Economic literature is primarily concerned with the negative effects of tying only when it involves restrictive circumstances, such as a regulated good being tied to an unregulated good (and thus raising questions of regulated prices subsidizing unregulated goods). Tying of goods benefiting from economies of scale may raise similar issues. See Daniel J. 
A second type of private use strategic behavior is a mix between the content and distribution levels. It involves situations in which the owner licenses use of an information good based on the potential use proposed by or expected of the user. Where the use is viewed as being critical of or otherwise negative toward the information owner, the use is withheld. Where the use is viewed as positive, it will be allowed. Recall the earlier book review example where the book's author or publisher is more likely to permit a direct quote from the book if the proposed review will be a positive one.

The resulting interaction occurs at both the content and the distribution levels. A negative review may lower demand for the book. This is the effect that the information owner wants to prevent. But it will also have the effect of precluding criticism, or content level interactions, surrounding the book. Where only positive discussions of a new information product can occur, content level interactions will suffer significantly. Of course, the primary reason for the decision to preclude the quote need not be economic; it can also be based on author pride, or a desire to suppress dissent about the ideas contained in the information of the work. Such reasons constitute a purely non-economic, indeed, an economically irrational, reason for withholding permission. ${ }^{180}$ Of course, discrimination need not be explicitly based on the granting of or refusal to grant a license. Information owners may also use price discrimination to mimic these effects, charging a prohibitively high price for access they wish to discourage or prevent.

Finally, the limiting of fair use, which is a constitutionally required ${ }^{181}$ and statutorily provided ${ }^{182}$ common use of information, through technological methods should be considered a private use strategic behavior. ${ }^{183}$ This is another act that affects interactions at both the content and the distribution levels.

Gifford, The Antitrust/Intellectual Property Debate: An Emerging Solution to an Intractable Problem, 31 Hofstra L. REV. 363 (2003); James B. Speta, Tying, Essential Facilities, and Network Externalities: A Comment on Piraino, 93 Nw. U. L. REV. 1277 (1999).

180. Howard Hughes, for example, attempted to purchase the copyright to articles that were being used in an unauthorized biography of him, with the eventual aim of stopping the biography. He was unsuccessful. See Rosemont Enters., Inc. v. Random House, Inc., 294 N.Y.S.2d 122 (N.Y. Sup. Ct. 1968), aff'd, 301 N.Y.S.2d 948 (N.Y. App. Div. 1969).

181. See Feist Publ'n, Inc. v. Rural Tel. Serv. Co., 499 U.S. 340, 349-50 (1991).

182. See 17 U.S.C. $\S 107$ (2000).

183. See Georgia K. Harper, Copyright Endurance \& Change, 35 EduCAUSE REV. $20,24(2000)$. 
Strategic behavior in the semicommons of the open fields involved the physical elements of farming and grazing. Strategic behavior in information ownership is a more complex matter. It involves layers of content and distribution level interactions, not simple physical burdens and benefits. But the strategic behaviors used to maximize gain in the information semicommons are still identifiable, and while other strategies may exist, ${ }^{184}$ those identified here will serve sufficiently to advance the core argument of this Article: that information ownership is a semicommons, complete with a dynamic relationship between private and common uses, and strategic behaviors engaged in by both private and common users. We now turn to a discussion of how the semicommons addresses the strategic behaviors identified above.

\section{b) Avoiding Strategic Behavior}

Strategic behavior in the open fields was avoided through a combination of norms, physical controls (technology and architecture), and law. ${ }^{185}$ Strategic behavior in the information semicommons is dealt with in a similar manner: law, norms, and controls work together to combat strategic behavior in information. ${ }^{186}$

One of the simplest methods for controlling strategic behavior is the requirement that property rights in information not be automatically perpetual. The four legal schemes of information ownership-copyright, patent, trademark, and trade secret-provide for the time and manner in which rights end. Copyright and patent law provide express terms of protection, ${ }^{187}$ whereas the protection provided by trademark and trade secret law is of indefinite but terminable length. ${ }^{188}$ While strategic behavior on the part of the private user is still a concern during the term of protection, the

184. For example, as to trademarks, one might use another company's or product's trademark so as to try to fool consumers into believing that the trademarked product is associated with his product. Another is "over enforcement," the use of legal action or the threat of legal action to dissuade common uses that are, in reality, non-strategic and permitted.

185. Smith, supra note 7, at 168-69.

186. Neal Kumar Katyal, Architecture as Crime Control, 111 YALE L.J. 2261, 2262 (2002).

187. The life of the author plus seventy years in the case of copyright for a natural individual; in the case of works for hire the period is either ninety-five years from publication or one-hundred and twenty years from creation (whichever is shorter). 17 U.S.C. $\S 302$. In the case of patent, it is twenty years from the date of filing for the patent. 35 U.S.C. $\S 154$ (2000).

188. Trade secrets are lost when the holder fails to take adequate measures to protect them. Trademark protection is lost if the mark becomes generic, or if it is abandoned (no longer used in commerce). 
prospect of eventual termination of an owner's rights may serve to moderate the effect as owners who demand too high a price for their information goods may find users waiting until they are no longer protected.

Another method used to dissuade strategic behavior is the use of enforcement actions by information owners. Where information owners may bring lawsuits for the unauthorized use of information, common users may reduce their strategic behavior.

Yet another powerful method of combating strategic behavior is the use of definitions that set the boundaries of information protection. For example, copyright law protects particular expressions of information fixed in a tangible medium; ideas may not be copyrighted. ${ }^{189}$ This powerful method of defining the applicability of the statutes, and in so doing defining the contours of the property, limits the ability of private users of information to behave strategically. As noted above, the idea/expression dichotomy has come under attack in recent years as unworkable, but its underlying theory remains doctrinally sound: while it may be useful to provide incentives to owners to create and invent, it does too much violence to constitutional notions of free speech to provide for ownership of ideas. ${ }^{190}$ Protection of particular expressions of ideas is one thing; protecting the ideas themselves is another. Were ownership to be extended to the ideas themselves, speech would be unquestionably diminished. ${ }^{191}$

The fair use provision in copyright law is one of the best examples of an explicit statutory provision that helps to define common use rights of information. ${ }^{192}$ Fair use serves to exclude from infringement claims uses relating to "criticism, comment, news reporting, teaching (including multiple copies for classroom use), scholarship, or research ...."193 The fair use provision demonstrates that the ownership of information exists in a semicommons. ${ }^{194}$ It protects common users' rights to use information to

189. See Harper \& Row Publishers, Inc. v. Nation Enters., 471 U.S. 539, 547 (1985).

190. See Feist Publ'n, Inc. v. Rural Tel. Serv. Co., 499 U.S. 340, 349-50 (1991); see also Cohen, supra note 101.

191. Note that strategic behavior by information owners approximates this result even where ideas cannot be protected. Howard Hughes, for example, in an attempt to stop the publication of an unauthorized biography, purchased and then refused to license for purposes of the biography the historical sources the biographer had used to develop his work. See supra note 180.

192. 17 U.S.C. $\S 107$.

193. Id.

194. That fair use shows the inherent nature of information as a semicommons does not contradict earlier statements that fair use is viewed as fair use of someone else's property. See supra note 2 and accompanying text. Rather, it is an acknowledgement that fair use plays an integral role in the scheme we perceive as creating information owner- 
criticize information owners, even in the face of the information owners' explicit objection. It thus combats the strategic behavior certain to arise when private and common uses must coexist. ${ }^{195}$

In the open fields, technology and architecture were also used as methods of avoiding strategic behavior. ${ }^{196}$ As the architecture for information is almost purely technological, these two methods of avoiding strategic behavior are blended for purposes of description. This should not be read to indicate that these methods are somehow less powerful in the information context. In fact, they may be more powerful than was the scattering of privately owned plots in the open fields. For example, digital rights management ("DRM") technologies, such as the DVD CSS encoding system, ${ }^{197}$ provide potentially absolute bars against actions that private users consider strategic on the part of common users. ${ }^{198}$ Where technology manufacturers and information producers cooperate to assure technological protective measures are implemented, architecture and technology combine to provide what is a generally strong, effective, and inexpensive method of combating strategic behavior. ${ }^{199}$

Given the ubiquitous networked environment in which we live today, and the existence of peer-to-peer networks, private information owners have had to combat the allegedly strategic behaviors of common users in the trading of copyrighted files, such as music and movie files. One technical method adopted to combat such trading is the release of "fake" files onto the networks. ${ }^{200}$ The files are identified as "real" files, but they are in fact either incomplete or contain an audio recording that condemns the

ship, but that it is wrongly viewed as a tolerated infringement. A more accurate description of fair use is that offered here: fair use is part of what shows us that we have not gone far enough in our thinking about information as property; we have not asked what kind of property our structures create. When we do, we no longer see fair use as tolerable or tolerated infringement, but as a crucial element in the nature of private and common uses of information.

195. Note that fair use is generally perceived as a constitutional requirement. Too much change in the landscape of fair use, and the Supreme Court would reject the changes based on the needs of the First Amendment. This is an additional reason why all information could not be owned. In other words, the constitutional fair use requirement is another reason why information ownership must be a semicommons.

196. Smith, supra note 7 , at 161 .

197. See supra note 23.

198. See Universal City Studios, Inc. v. Corley, 273 F.3d 429 (2d Cir. 2001) (holding that the DMCA anti-circumvention provisions prohibit circumvention of the DVD CSS)).

199. As with other methods of avoiding strategic behavior, technology can also be used on the private side as a method of facilitating private strategic behaviors.

200. See, e.g., Doug Bedell, 'Spoofs' Plague Music Swappers, The Dallas MoRNING NEWS, July 11, 2002, at 3D. 
trading of copyrighted works. Users who wish to act strategically by trading copyrighted files are already implementing methods to avoid fake files. ${ }^{20}$ The release of and reaction to fake files are clear examples of how private and common users adjust their actions to changes in technology and adopt technological methods to avoid strategic behavior in the information semicommons.

\section{c) The Digital Revolution and Strategic Behavior}

To develop an understanding of how strategic behavior occurs in the information semicommons, it is necessary to consider how the digitalization of information affects information goods and information related actions. Strategic behaviors in information related goods are not new. Detecting counterfeits in the fine art world, for example, is a field unto itself, an important component of the market for rare art. ${ }^{202}$ What has changed is the cost of engaging in these strategic behaviors. Costs have changed because of technology, and all three aspects of the property rights paradigm-possession and use, alienation and distribution, and exclusion-are affected by this change. ${ }^{203}$ Technology now allows or has the imminent potential to allow increased ease of copying of digital goods, increased ease of distribution of digital goods, and, although apparently in contradiction to the first two changes, ${ }^{204}$ increased potential for technological exclusion of common users from use. ${ }^{205}$

Each of these changes has altered the way in which strategic behaviors affect the balance of uses in the information semicommons, and the changes have occurred both in terms of common uses and private uses. Digital works can be easily and exactly copied. This decreases the marginal cost of production of information goods to essentially zero, but creates new difficulties for manufacturers of digital goods.

201. One response has been the development of software that allows peer-to-peer users to listen to the files they are downloading as the download is occurring, which allows them to abort downloads of fake files.

202. See Raul Jauregui, Comment, Rembrandt Portraits: Economic Negligence in Art Attribution, 44 UCLA L. REV. 1947, 1960 (1997).

203. JoRge REINA SCHEMENT \& TERRY CURTIS, TENDENCIES AND TENSIONS OF THE INFORMATION AgE: The PRODUCTION AND Distribution of INFORMation IN THE UNITED STATES (1995).

204. The Internet is often the example of nearly costless distribution, but even the existence of recordable CDs, each costing only a few pennies when purchased in quantity, has lowered distribution costs.

205. Exclusion is accomplished through the use of DRM technologies, which allow a creator or distribution to "lock" or control uses engaged in by users. Supplemented by the DMCA, which criminalizes circumvention of such technologies, exclusion rights in information appear at this time to be particularly strong. See 17 U.S.C. $\S 1201$ (2000). 
In addition to enabling the creation of perfect copies, digital technology has lowered the cost of distribution of digital goods. In place of a production plant with systems and workers producing, packaging, and shipping each good, digital goods are distributed via networks such as the Internet with virtually no overhead. This means that the marginal cost of distribution is also zero or close to zero. It also means that nonexcluded (and thus nonpaying) users can themselves distribute such goods inexpensively, essentially at the cost of their time used to obtain or distribute the goods.

Finally, digital technology has changed the way that users may gain access to digital goods. In the past, if a publishing house wanted to prevent a consumer from reading a book more than, for example, five times, there was little it could do to put its desire into practice. In today's digital markets, however, if the book is distributed in digital (often referred to as "electronic" or "e") format, the code that underlies the display of the book on the viewer or computer might limit the number of times the pages can be viewed. ${ }^{206}$ Producers, therefore, at least theoretically, may have the technological ability to control access to information goods in a way that was not possible before. This can, of course, lead to strategic behavior on the part of both producers, who may attempt to be overly restrictive in the rights they provide, as well as users, who may attempt to circumvent the protections put in place by the producer and thus obtain an unrestricted or less restrictive version of the good at the restricted price.

The effect of these changes brought about by the digital revolution is not yet fully cognizable. What we can say about them is limited to current ad hoc observation and predictions about the future. The technology itself is not settled. The "technological arms race"207 in digital works, where owners continually develop new protection that is eventually circumvented, is ongoing, and the pace of technological development seems to be slowing little, if at all. The point in discussing the effects of digital production of goods here is simply to highlight the ways in which digital goods are important to our understanding of strategic behaviors. The digi-

206. See United States v. Elcomsoft, 203 F. Supp. 2d 1111 (N.D. Cal. 2002) (describing the eBook software developed by Adobe Systems for this purpose, in the context of a constitutional challenge to the applicability of the DMCA to software developers).

207. See Trotter Hardy, Property (and Copyright) in Cyberspace, 1996 U. CHI. LEGAL F. 217, 251 (1996) ("The problem with this scenario is that it constitutes a kind of wasteful 'arms race' of technological-protection schemes, with each side increasing its spending to outperform the other's technology."). Note that the "property" in Hardy's title is in reference to property rules versus liability rules, and not property as a conception of ownership per se. 
tal nature of information goods in the modern world overlays nearly all strategic behavior questions today, and thus must be kept in mind when discussing modern information goods.

\section{Conclusion}

By statute and judicial interpretation, information can be owned. The structure of the property scheme that describes the ownership of information, however, is not the dichotomy of private versus common use. It is a semicommons, complete with a strong dynamic relationship between the private and common uses, and a laundry list of both strategic behavior and methods for avoiding strategic behavior. Now that we have examined the positive claims concerning the nature of information ownership, we will discuss the normative implications of this new perspective.

\section{THE SEMICOMMONS EFFECT}

\section{A. Introduction}

Considering information ownership as a semicommons provides us with an additional analytical tool with which to understand information and information use. ${ }^{208}$ It provides additional explanatory power with which to consider the changes occurring in the information age. For example, what is the purpose of fair use in a world of information goods. Wendy Gordon ${ }^{209}$ has offered a justification for fair use based on market failure. Where market failures in information exchanges could be worked out, such as through priceless or nearly priceless transactions in the "point and click" world of the web, fair use seems harder to justify. ${ }^{210}$

Semicommons theory has the potential to put this debate to rest. Fair use exists as part of the recognition of the nature of information ownership. Attempting to privatize all information uses is destined to fail due to the nature of information and its uses and ownership. All information cannot be owned. Private uses must interact with common uses. Semicommons theory best recognizes this implication and is best used to tease out the implications of this conclusion.

208. This section of the Article owes a great deal to Professor Timothy Lytton of Albany Law School, who asked the following question while an earlier version of this Article was being presented at a Faculty Workshop: "So what? Aren't there other ways of achieving the same ends without relying on a new and unique application of property theory?" The answer is no, but I am indebted to Professor Lytton for asking the question.

209. See Wendy J. Gordon, Fair Use as Market Failure: A Structural and Economic Analysis of the Betamax Case and Its Predecessors, 82 COLUM. L. REV. 1600 (1982).

210. See id. 
While it might be possible to obtain similar results within each of the four intellectual property regimes, namely copyright, patent, trademark, and trade secret, absent the semicommons, the justification for laws that authorize "infringement" of private users' property rights required within each area would necessarily be different. For example, in copyright, a rereading of fair use that includes overall welfare calculations rather than private owner gain might be used to save peer-to-peer networks. But fair use would play no role in considering extensions to the length of protection offered for patents. In such a case, new arguments would be needed, but without the semicommons, such arguments would most likely seek to maximize the benefits of either the private or the common use.

In contrast, semicommons theory allows us to perceive the structure of information ownership more clearly and to acknowledge the dynamic relationship that must exist due to the nature of information. It is nearly impossible to conceive of a world in which all use of information is private, necessitating that any use by any person be authorized by an owner. This is one of the primary differences between land and information. It is possible to conceive of a world in which all land is subject to private use rights, and any use of any land must be authorized by its owner. In other words, it is possible to conceive of a world in which there are no common uses of land. That does not work in the information arena; as we have seen above, all information cannot be owned, regardless of how we try to categorize its various aspects. ${ }^{211}$

The semicommons effect, then, helps us to more accurately describe what information ownership looks like, how private and common uses of information are not only currently interacting, but must continue to interact due to the very nature of information itself. The normative effect of this positive state of affairs has the potential to be quite profound.

\section{B. The Normative Effect of the Semicommons Approach: Acknowledging Reality}

The primary normative implications that flow from understanding information ownership as a semicommons derive from the distinctions between the nature of land as property and the nature of information as property. Where information as a whole cannot be subject to precise ownership, where certain individual attributes of information cannot be owned in any sense of the word, it is inappropriate to continue along a path that is based on the premise that increased private use will yield increased wel-

211. This is not to argue that very important information cannot be owned or controlled, or even that certain categories of information cannot be owned. 
fare. This is the argument against the commons in land; left as a pure commons, the resources of the land will be overutilized to the point of depletion. ${ }^{212}$ Placed in private use, so the argument goes, the resources will be used as efficiently as possible, thereby increasing the overall welfare.

In the context of information, however, this argument falls short of the mark. It is based on the false premise that all information can be privatized, or that certain information can be made completely and efficiently private, while at the same time other information will remain (ostensibly by choice) in the public domain. As a positive matter this is simply not the state of affairs as to information. Instead, information ownership exists in a semicommons, with a dynamic relationship between private and common use of the same information. Judicial interpretations that rely on the old private/common use dichotomy to interpret current and future statutes are destined to twist efficiency rather than enhance it as the law struggles to address information ownership.

The normative claim is thus that judicial decisionmakers, administrative agencies, and legislative policymakers must take into account not simply the desires of and benefit to private users when making decisions and adopting laws, but also the overall effect of those decisions and laws on the dynamic relationship between private and common uses. These interests must be balanced with an aim toward increasing overall welfare, not simply the welfare that is assumed to result from increasing private use. The implications of this change in perspective are made clear as we return to our peer-to-peer example.

\section{Peer-to-Peer Revisited}

After considering the primarily positivist claims above regarding the existence and operation of the information semicommons, it is useful to clarify the application of the theory with an example of how it applies to the issues in a current and ongoing debate regarding strategic behavior in the information semicommons. We need not revisit detailed theories of peer-to-peer sharing at this point, nor deeply investigate the factual scenarios involved in current realworld file trading to ascertain that semicommons theory provides us with background to more fully understand and analyze the interaction between the private and common uses of information.

212. Garrett Hardin, The Tragedy of the Commons, 162 SCI. 1243, 1243-48 (1968); see also ELINOR OSTROM, GOVERNING THE COMMONS: THE EVOLUTION OF INSTITUTIONS FOR COLlECTIVE ACTION (1990). 
Copyright owners consider file trading a damaging kind of strategic behavior on the part of common users. Under a traditional property conception of information ownership, the files are "owned by" their private owners. The only uses allowed are those authorized by the owner, who is provided with authority in law to exclude others from use. This matches with our understanding of property. Although limitations on ownership, such as fair use, may apply, copyright owners are otherwise correct in stating that file traders are behaving illegally.

Within this traditional conception, common users of copyrighted files have offered myriad defenses for their activities. Some of these fit neatly into the private/common paradigm set out in copyright law-fair use in particular. Large scale trading, however, would seem to be outside of fair use, and courts have found this to be the case in litigation involving the peer-to-peer software applications. ${ }^{213}$ From the semicommons perspective, a more interesting defense offered by users is that file sharing is justified because it increases demand for information by providing users, not with a substitute for the original, but with an opportunity to sample the original and determine whether it is a good worth purchasing. Restated in the terms of the information semicommons, the claim is that peer-to-peer file sharing on the whole creates positive distribution and content level interactions in information. It is a claim that outside of a semicommons understanding would be irrelevant-that by somehow "stealing" property, welfare is increased. Within the semicommons notion, the claim takes on new meaning and importance, and gains legitimacy based on the nature of information ownership.

This, of course, does not mean that common users who make these claims about peer-to-peer file sharing are correct about the effect their activities have on the market for information. It does mean that if we acknowledge that information ownership is a semicommons and look to maximize the dynamic relationship between private and common uses, we would seek empirical or theoretical evidence to support or deny the users' claims. ${ }^{214}$ Absent a semicommons understanding of information ownership, empirical evidence of the effect of peer-to-peer file sharing on the

213. See supra Part II.

214. While the Ninth Circuit's first Napster decision discusses the proof offered by Napster of this very effect, recall that the court explicitly rejected the notion that even this allegedly positive effect could preclude a finding of infringement, as Napster displaces the record companies' abilities to enter the digital market. Napster II, 239 F.3d 1004, 1081-19 (9th Cir. 2001). Even if Napster had this effect, it's an effect that-according to the Napster courts--should be controlled by the copyright owners, emphasizing the private nature of the use as controlling. See id. 
purchase of information goods is irrelevant. Within the semicommons, that information is critical to making correct policy and legal choices to maximize the efficiency and welfare generated by the system.

\section{Using Content and Distribution Level Interactions in Decisionmaking}

Concepts of content level and distribution level effects should influence the decisionmaking for information usage. In terms of functional implementation, it would be most convenient to devise a sliding scale whereby common uses receive less protection at the distribution level than at the content level in the semicommons. Such a scheme, however, would oversimplify the complex interaction between common and private uses.

Instead, we require a model more clearly approximating the interaction of common and private uses at the content and distribution levels. As previously discussed, uses at the content levels interact with the distribution levels. Returning again to our example of a book review, a reviewer may add to or subtract from the theories presented in the book. This is a content level effect that may in turn influence the distribution level of the book. For example, book sales may decline because the reviewer criticizes the content of the book. This resulting loss in sales should not be viewed as somehow negative in and of itself. In line with our understanding of robust speech protections, it seems appropriate that imperfect information, or information that can be improved upon, should experience lower distribution. In this case, the new information becomes the superior good and should, all things being equal, dominate the information market for that particular content.

Even common use of information exclusively on the distribution level should likewise be encouraged and protected. For example, a review simply criticizinz the author's writing style is a critique that does not go to a content level interaction because the reviewer is not attempting to interact with the content by advancing or commenting on it per se. Rather, the review goes to the form of the information. Such common uses with pure distribution level effects are also desirable in the semicommons.

But allowing all common uses without restraint would irrevocably erode the underpinnings of the information copyright system. There is a point at which common use must yield to private use. ${ }^{215}$ The semicommons theory provides us with a functional guide to such situations. When an original information good is substituted with an identical or nearly identical information good, the distribution of the original information

215. Recall that this Article assumes, neutrally, that private incentives are necessary. 
good is impaired purely at the distribution level. According to the semicommons theory, we must not ask whether the information's private creator is losing opportunities to benefit from her information, but rather must consider whether the private information creators still have sufficient incentives to continue creating information. If they do, the common use should be allowed as a reflection of the understanding of the nature of private and common use interactions.

The presumption in favor of allowing the use is stronger still where content level interactions also take place. Even if many information producers would lose significant incentives to continue producing information due to common use at the content level, the common use should be allowed so long as there is sufficient incentive for private information users to continue to produce some information and so long as the quality of the perceived information good is perceived as increasing due to the content level interaction (for example, because false information is displaced with true information or because higher standards are used in information production).

In the Napster case study, this means that we would need to investigate claims that audio sales increased because of peer-to-peer file sharing. If theoretical or empirical evidence were to support this assertion, the common use should be allowed. Common users could share their files on the network without fear of displacing the incentives necessary to encourage that work to begin with. Such a result would be far different from the restrictions that were imposed on Napster, which precluded the trading of copyrighted works. Under a semicommons regime, the trading itself would be permitted through an understanding of the content and distribution level effects the trading has on the semicommons, and not simply what effect the common use has on the private user's rights.

\section{CONCLUSION}

Henry Smith's explanation of the semicommons in the open fields provides a powerful theory that can be applied to information ownership. The semicommons form not only acknowledges this dynamic interaction, but also articulates the methods used to discourage the strategic behavior that is likely to arise in a semicommons. As sources of property rights, the statutory and judicial doctrines surrounding copyright, patent, trademark and trade secret play an integral role in the information semicommons. With methods in place to avoid strategic behavior-methods that adapt to changes in law and technology-semicommons theory allows us to under- 
stand more fully the nature of an overall property system and to view the interactions in the system as related, as opposed to purely antagonistic.

As shown in the peer-to-peer example addressed in this Article, many arguments and discussions that are now rejected under the rubric of fair use should be given careful consideration when the information semicommons model is properly understood. Some of these are already included in the fair use doctrine, but others are not. As shown by the peer-topeer example, the paradigm shift would produce valuable insights for decision making regarding information ownership.

The effect of acknowledging that information ownership forms a semicommons is perhaps radical. It requires that we move our notions of information ownership away from the land and asset-based model toward a model that recognizes and enhances the dynamic interaction between information uses. Such a step would, however, allow us to come to terms with the changing nature of information production in the digital age.

The antagonistic duality between private and common use is not reflective of the reality of information ownership. The semicommons is. 
BERKELEY TECHNOLOGY LAW JOURNAL 